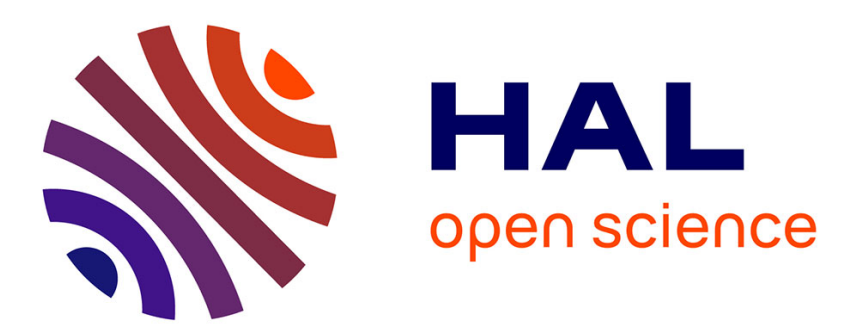

\title{
Anti-Influenza Drug Discovery and Development: Targeting the Virus and Its Host by All Possible Means
}

Olivier Terrier, Anny Slama-Schwok

\section{To cite this version:}

Olivier Terrier, Anny Slama-Schwok. Anti-Influenza Drug Discovery and Development: Targeting the Virus and Its Host by All Possible Means. Antiviral Drug Discovery and Development, pp.195-218, 2021, 10.1007/978-981-16-0267-2_8. hal-03286916

\section{HAL Id: hal-03286916 https://hal.science/hal-03286916}

Submitted on 1 Oct 2021

HAL is a multi-disciplinary open access archive for the deposit and dissemination of scientific research documents, whether they are published or not. The documents may come from teaching and research institutions in France or abroad, or from public or private research centers.
L'archive ouverte pluridisciplinaire HAL, est destinée au dépôt et à la diffusion de documents scientifiques de niveau recherche, publiés ou non, émanant des établissements d'enseignement et de recherche français ou étrangers, des laboratoires publics ou privés. 


\title{
Chapter X:
}

Anti-influenza drug discovery and development: targeting the virus and its host by all possible means

Olivier Terrier ${ }^{1}$, Anny Slama-Schwok ${ }^{2}$

\begin{abstract}
Influenza infections remain a major and recurrent source of public health concern. Together with vaccines, antiviral drugs play a key role in the prevention and treatment of influenza virus infection and disease. Today, the number of antiviral molecules approved for the treatment of influenza is relatively limited and their use is threatened by the emergence of viral strains with resistance mutations. There is therefore a real need to expand the prophylactic and therapeutic arsenal. This chapter summarizes the state of the art in drug discovery and development for the treatment of influenza virus infections, with a focus on both virus-targeting and host-cell-targeting strategies. Novel antiviral strategies targeting other viral proteins or targeting the host cell, some of which are based on drug repurposing, may be used in combination to strengthen our therapeutic arsenal against this major pathogen.
\end{abstract}

Keywords: antiviral, drug repurposing, replication, entry, immune modulator

\section{Abbreviations:}

CoV: Coronavirus

COX: cyclo-oxygenase

HA: hemagglutinin,

IAV: Influenza A virus,

IFN: Interferon

M2: Matrix 2

NA: neuraminidase,

NOX: NADPH oxydase 
NP: nucleoprotein,

p09: H1N1 2009-pandemic strain

PA: polymerase acidic subunit,

PB1: polymerase basic subunit 1,

PB2: polymerase basic subunit 2,

PPI: protein-protein interaction

RdRP: RNA-dependent ribonucleoprotein complex

RIG-I: retinoic acid inducible gene-I

TNF- $\alpha$ : Tumor necrosis factor- $\alpha$

vRNP: viral ribonucleoproteins

1. CIRI, Centre International de Recherche en Infectiologie, (Team VirPath), Univ Lyon, Inserm, U1111, Université Claude Bernard Lyon 1, CNRS, UMR5308, ENS de Lyon, F-69007, Lyon, France. Email : olivier.terrier@univ-lyon1.fr

2. Sorbonne Université, Centre de Recherche Saint-Antoine, INSERM U938, Biologie et Thérapeutique du Cancer, Paris, France. Email : Anny.Slama-Schwok@inserm.fr 


\section{Introduction}

2 Influenza infections remain a major and recurrent source of public health concern. Influenza viruses are

3 the causative agents of annual flu epidemics, marked by up to 1 billion infections and 300,000-650,000

4 deaths worldwide, with a huge economic burden in terms of hospitalization costs and work/school absenteeism (WHO, 2018; [56]). In addition, Influenza A viruses (IAV) have been the cause of several pandemics in recent human history, from the Spanish Flu H1N1 in 1918 to the more recent H1N1 2009 pandemic [71].

8 Together with vaccines, antiviral drugs play a vital part in the prevention and treatment of influenza

9 virus infection and disease. During a normal influenza season, antiviral drugs are mainly used to treat critically ill patients, such as those hospitalized in intensive care. In a pandemic context, pending the availability of a vaccine, antiviral drugs are essential both to treat patients who have been infected and to prevent infection in those exposed, including healthcare workers. Today, the number of antiviral molecules approved for the treatment of influenza, based on the targeting of viral proteins, is relatively reduced and threatened by the emergence of strains with resistance mutations. There is therefore a real need to expand the prophylactic and reinforce the current therapeutic arsenal. This chapter summarizes the state of the art in drug discovery and development for the treatment of influenza virus infections, with a focus on both virus-targeting and host-cell-targeting strategies (Figure 1). Novel antiviral strategies targeting other viral proteins or targeting the host cell, some of which are based on drug repurposing, may be used in combination to strengthen our therapeutic arsenal against this major pathogen.

\section{2- From existing classic antiviral drugs to new pre-clinical candidates}

\subsection{M2 ion channel blockers (amantadine/rimantadine)}

Influenza A M2 is a multifunctional viral homo-tetramer protein [57]. Its transmembrane (TM) domain forms a proton channel. This channel is required for acidification of the viral endosome formed after fusion and endocytosis of the virus within the host cell. This process allows viral ribonucleoproteins (vRNPs) to dissociate from the matrix 1 (M1) protein. The proton conductance mechanism relies on the 
121]. Channel blockers interfere with the proton conductance mechanism by binding to the

31 transmembrane pore [137] (Figure 2). When proton conductance through M2 is blocked by the adamantane drug, this dissociation is prevented and the virus is no longer able to replicate. In recent years, adamantane drug-resistant mutants have become prevalent in circulating viruses. The two most prevalent drug-resistant mutants are S31N, L26F and V27A, all of which are located in the transmembrane region of M2 [138]. Figure 2A shows the strong interaction of amantadine with V27 in the upper part of the pore. Upon drug-resistance V27A mutation, this interaction is lost. Recentlydeveloped spiro-amantadyl amine effectively binds to A27 of the pore (Figure 2B) [136]. Recently, new amantadine derivatives effective against double mutants M2-S31N/L26I and M2-S31N/V27A viral strains have been developed by Musharrafieh et al [91]. The antiviral efficacy of such compounds is summarized In Table 1. M2 resistance mutations in H1N1/H3N2 circulating strains prompted the WHO to remove both amantadine and rimantadine from the list of recommended anti-influenza agents for clinical use in 2009 [34].

\subsection{Neuraminidase (NA) and hemagglutinin (HA) inhibitors}

\subsubsection{NA inhibitors}

NA inhibitors competitively inhibit and prevent cleavage of the terminal sialic acid residues from glycoproteins and carbohydrates displayed on the surface of mammalian cells and influenza virus particles. Binding of virions to uncleaved sialic acid then impairs virion release and dissemination. Among these NA inhibitors, peramivir, zanamivir, oseltamivir carboxylate are the most frequently prescribed drugs and considered standard-of-care for influenza management (Table 1 and Figure 3). Resistance to oseltamivir can develop rapidly in both experimental settings and the clinic, and typically originates from substitutions at signature resistance sites in the viral NA protein such as H274Y and I223R (predominant in H1N1 and H5N1 viruses), and E119V, R292K, or N294S (predominant in H3N2 viruses). These three NA inhibitors are currently licensed worldwide for the treatment of influenza A and $\mathrm{B}$ infections, oseltamivir being the most widely used. There is still a lot of debate about the 
derivatives, targeting either multiple sites or different NA cavities (as the " 430 " or the " 150 " cavity) have been recently developed. Some of these derivatives are very potent against multiple IAV and IBV strains, including oseltamivir-resistant ones (Table 1).

\subsubsection{Hemagglutinin inhibitors}

The surface glycoprotein HA enables viral entry into host cells by binding to cell-surface, sialic-acidcontaining glycans and mediating fusion between the viral and host membranes in endosomal compartments. HA is composed of head (HA1) and stem (HA2/HA1) domains. As the regions on HA involved in binding and fusion are highly conserved, they are attractive sites for the design of new antivirals (Table 2). The broad-spectrum antiviral drug arbidol shows efficacy against influenza viruses by targeting the hemagglutinin (HA) stem region [63]. This molecule is currently licensed in Russia and China for the treatment of influenza and other infections [8]. A challenging strategy aiming at mimicking antibodies binding sites was successfully developed by Wilson et al, targeting the conserved stem region and more recently at the interface of the trimeric head region $[4,141,155]$ (Figure $\mathbf{4 A}$ ). The binding sites of the binding sites for CBS1117 and JNJ4796 were both found in the stem region close to the fusion peptide, highlighting the possibility of further structure-based designed compounds [2]. De novo design of high-affinity trimeric proteins called "HA mini-binders" that bind influenza A hemagglutinin trimer at a conserved region binding site (Figure 4B) [129]. These molecules were developed as alternative to antibodies. These and other compounds are summarized in Table 2.

\subsection{Polymerase - nucleoprotein- RNA inhibitors}

\subsubsection{Polymerase/endonuclease inhibitor (favipiravir, Baloxavir marboxil)}

Influenza virus transcribe and replicate their genome in the nucleus of infected cells by the means of a hetero-trimeric polymerase, PA, PB1 and PB2. The polymerase complex function requires the nucleoprotein NP, a protein associated with- and protecting the segmented genomic RNA. Therefore, all four proteins are essential for replication. Whereas replication requires the generation of complementary positive polarity RNA intermediates (cRNA) that are then copied into progeny negative 

inhibitors $[61,62,87,170]$. phosphodiester bond formation. and pimodivir (PB2, Figure 5B). and resistance.

polarity segments (vRNPs), viral message is directly synthesized from vRNPs. Since the influenza virus RdRP lacks enzymatic activity to form 5' mRNA cap structures, endonuclease activity of the PA subunit is necessary for the generation of viral mRNAs through transfer of 5'-capped RNA primers derived from host mRNAs in a cap-snatching mechanism. The endonuclease active site of PA-N terminal comprises a histidine and a cluster of three strictly conserved acidic residues (Glu80, Asp108, Glu119), which coordinate (together with Ile120) one or two manganese or magnesium ions [32] (Figure 5A). PB2 is involved in binding of the capped primers, whereas the PB1 subunit harbors enzymatic activity for

Several classes of inhibitors are in the clinics (Figure 6): baloxavir (PA), favipiravir (PB1)

\subsubsection{Pre-clinical compounds targeting the polymerase PA-PB1 and PA subunits; escape mutations}

Pre-clinical candidates, some of them being listed in Tables 3 and 4, are in development, benefiting from the recent insight provided by the structures of PA-PB1, PB1-PB2 and whole polymerase complex with or without RNA by X-ray crystallography $[26,48,95,102,110,130$, 146] and cryo-electron microscopy [23, 42, 44, 111, 144]. The error-prone nature of influenza viral replication can rapidly generate point mutants for the selection of resistance that have seriously compromised the efficacy of influenza therapeutics. Escape mutations were identified under the pressure selection of PA inhibitors: the signature hotspot for escape from baloxavir marboxil is PA residue 38, for which several substitutions (PA I38T/M/F) have been described [96]. Similarly, escape mutations from L-742.001[127] and RO-7 [70] treatments were also characterized although in laboratory resistance-assays, escape mutants were not detected after multiple passages for L-742.001. While very tight affinities have been achieved by designing metal binding inhibitors to block the active site of the endonuclease activity in PA N-terminal (Table 2), the appearance of escape mutants often rapidly 
116 Different strategies have been undertaken to attempt overcoming induced resistance. Interfering with its

117 proper assembly of the RdRP polymerase to inhibit function is pursued using protein-protein interaction

118 (PPI) inhibitors. The advantage of such an approach is the relatively large interacting surface between

119 the two proteins as compared to the binding site of an active-site ligand. Indeed, inducing simultaneous

120 mutation of at least one residue on both proteins while maintaining their interaction is less likely to

121 develop resistance and suggests that PPI inhibitors could be less prone to drug resistance than inhibitors

122 of enzyme active sites. The recent identification of a single- domain antibody (nanobody) allowing to

123 disrupt dimerization of FluA polymerase is among these lines [42]. PPI inhibitors have been developed

124 based on the structural insight given by PA-PB1 crystal structures in 2012 [81]. The inhibition of the

125 polymerase PA-PB1 subunit interface has become an active field of research with the goal of remaining

126 active against resistant strains to amantadine and to oseltamivir (Table 3). Recently, compound 12 was

127 identified by structure-based screening of compounds targeting the PA-PB1 structure. No resistant virus

128 was selected in vitro under drug selection pressure of compound 12a [164]. Moreover, derivatives of

129 cyclothiophene and R151785 were found active against multiple strains of Influenza A and B [31, 94,

$130 \quad 165]$.

131 Based on the ability of PA-PB1 to bind viral RNA, it is likely that novel types of inhibitors could be 132 developed by structure-based design [131]. Additionally, inhibitors targeting PA C-terminal [78] and its 133 interactions with vRNA or with PolII could be effective targets, based on the accumulating wealth of 134 structural data $[42,102,110,144]$ and deeper insight in the multi-protein assembly required for during 135 replication / transcription.

\subsubsection{Broad-spectrum inhibitors}

138 Favipavir is a drug with broad-spectrum antiviral activity in cell culture, inhibiting RNA viruses of the 139 arenavirus, bunyavirus, flavivirus, alphavirus, norovirus, picornavirus, paramyxovirus, and rhabdovirus

140 families, in addition to influenza viruses [160]. This drug is incorporated into newly synthesized RNA 141 by the viral polymerase in place of purines but not pyrimidines, resulting in increased frequencies of C142 to-U and G-to-A transition mutations. Although the barrier for resistance is relatively high, this drug 143 seems to present toxicity issues. $\mathrm{N}$ 4-hydroxycytidine (NHC) is also a broad-spectrum antiviral 
144 candidate, which showed oral efficacy against RSV and both highly-pathogenic avian and seasonal

145 influenza viruses as well as SARS-CoV-2 virus [140].

\subsubsection{Pre-clinical compounds targeting the polymerase PB2 subunit}

147 Crystal structure of the PB2 cap-binding domain have been exploited to develop different 7-

148 methylguanine derivatives [100]. Pimodivir (VX-787) is an inhibitor targeting the polymerase PB2

149 subunit at the $\mathrm{m}^{7}$ GTP-binding site, forming extensive stacking interactions with several aromatic

150 residues His (Figures 5B and 6). It inhibits influenza virus replication and reduced viral load in animal

151 infection models of $\mathrm{H} 3 \mathrm{~N} 2$ and $\mathrm{H} 1 \mathrm{~N} 1$ viruses, although potency was highest against H1N1 strains [9,

152 20]. Phase-2 clinical studies indicated that this drug is well-tolerated, reduced viral load, and resulted in

153 slightly faster resolve of clinical signs. Further derivatives of pimodivir have been designed [84].

154 Targeting the PB1-PB2 interface by PPI inhibitors has been challenging: although PP7 exhibited

155 antiviral activities against influenza virus subtypes A pandemic H1N1, H7N9 and H9N2, resistances

156 have been unexpectedly detected in laboratory assays [162].

\subsubsection{Pre-clinical compounds targeting the nucleoprotein or the nucleoprotein-RNA interactions}

158 The nucleoprotein associated with viral RNA and the polymerase complex is essential for transcription

159 and replication $[22,145,146]$. The assembly of NP-RNA oligomers into RNP has been determined by

160 cryo-electron microscopy studies $[3,22,23,146]$. In the X-rays structures of the NP [156], the protein

161 adopts a trimeric structure. NP self-association to achieve trimer formation is mediated by a flexible

162 tail-loop that protrudes into a pocket of the adjacent subunit, via the formation of a critical interaction

163 between R416 of one subunit and E339 of the adjacent subunit. The R416A mutant lacking this

164 interaction adopts a monomeric structure [16]. The native protein can also be purified in a monomeric

165 form at low salt and concentration conditions $[15,16,133]$. The ability to modify the oligomeric state

166 of NP is the structural basis of most NP inhibitors presently developed. Nucleozin was the first NP

167 inhibitor developed as a molecule impeding nuclear accumulation. Nucleozin enhanced higher order

168 structures [64]'[46]. Figure 5C shows the interactions of one of the nucleozin ligands found in the X- 
ray structure (PDB ID 5B7B) stabilizing the interface between two NP subunits [98]. Escape mutants to nucleozin have been identified in laboratory assays. The opposite approach to impede nucleoprotein

171 self-association has also been pursued by disrupting the important salt bridge R416-E339 mediating NP

172 oligomerization [123]. Recently, new compounds with high affinity for NP were designed stabilizing monomeric NP [150]. Impeding NP binding to viral RNA has been achieved by naproxen drug repurposing, naproxen being a known inhibitor of cyclo-oxygenase (COX)[73]. As NP oligomerization is enhanced by the presence of RNA, naproxen binding to NP reduced NP oligomers and favored monomeric NP. Docking and single mutations studies identified Tyr148, the only aromatic residue within the RNA binding groove and residues of the C-terminal part of NP R355, R361, Phe489 being involved in the interaction of naproxen with NP. Laboratory assays showed no resistance after 8 cell passages infected with Influenza A. Naproxen exhibited antiviral effects in mice models of Influenza A infection [33, 73] as well as Influenza B virus [168]. Further structure-based design yielded new naproxen derivatives with improved antiviral effects and selectivity for NP without COX inhibition

182 (Figures 5D and 6) [33, 134] (Table 4). Some of these derivatives were found inhibiting NP-PA 183 interactions [33, 143]. Naproxen derivatives also present antiviral properties against oseltamivirresistant strains [33]. Additional compounds with some similarity of their hydroxyquinoline scaffold to the methoxy naphthalene scaffold of naproxen called NUD were designed and were also found to be resistant in escape mutation laboratory assays [79].

\subsection{Drugs targeting the non-structural protein-1 (NS1)}

188 NS1 has a plethora of strategies to inhibit the host immune response due to its ability to establish

189 multiple protein-protein and protein-RNA interactions. NS1 hampers different pathways both in the

190 cytoplasm and in the nucleus of infected cells. NS1 antagonizes interferon-mediated antiviral host

191 response by binding to double-stranded (ds) viral RNA, thus protecting it from cellular factors, by

192 blocking retinoic acid inducible gene-I (RIG-I) and NF-kB activation. One pathway by which NS1

193 increases virulence is through the activation of phosphoinositide 3-kinase (PI3K) by binding to its $\mathrm{p} 85 \beta$

194 subunit [17]. NS1 has two structural domains-RNA-binding domain (RBD) and the effector domain 
196 effector domain have been designed with low micromolar antiviral efficacy [68] (Table 4).

\section{3. Host-targeting \& drug repurposing approaches for the treatment of influenza}

198 Considerable progress has been made in understanding the interactions between influenza viruses and

199 the host cell in recent years. In this context, and in light of the emerging problem of resistance to 200 available classical antivirals, many studies have focused on targeting host factors to limit virus 201 replication, but also to modulate host immune response. The targeting of host-factors and/or signaling pathways makes sense in the context of virally-induced hypercytokinemia (also known as "cytokine storm"), which is directly correlated with tissue injury and an unfavorable prognosis of severe influenza

204 [76]. Indeed, approaches to control or attenuate this disproportionate immune response are of particular 205 interest and are the subject of numerous pre-clinical and clinical studies. As with all viruses, influenza 206 viruses depend on cellular machinery for their replication and propagation. Many cellular factors 207 essential for the replication of influenza viruses have been uncovered through genome-wide RNA interference approaches $[65,69,86,128]$ but also more broadly through different integrated cell biology approaches using interactome and transcriptome data, for example [109, 148]. In order to list the

210 different host-targeting strategies developed, a distinction can be made between molecules with a mode 211 of action associated with a relatively well-defined stage of the viral cycle, and molecules associated with 212 the modulation of signaling pathways. It is these two main classes that will be described in the following 213 sections.

\subsection{Drugs targeting host cell component at different stages of influenza replication cycle}

216 The replication cycle of influenza viruses can be divided into several distinct phases, 1) entry 2) nuclear 217 import of viral genome (viral ribonucleoprotein; vRNPs) 2) genome replication and protein synthesis, 218 3) Nucleo-cytoplasmic export of vRNPs, and 4) plasma membrane transport and budding of neo-virions 219 (Figure 1). A number of molecules targeting host factors in these different steps, at different 220 preclinical/clinical development stages, are known today. 
221 Viral entry is a target of great interest, as it is likely to allow prophylactic approaches, by blocking the

222 infection in its early stages. One of the most advanced strategy consists to target the viral receptor.

223 DAS181 (Table 5) (Fludase, Ansun BioPharma) is a sialidase fusion protein that cleaves both the

224 Neu5Ac $\alpha(2,3)$ - and Neu5Ac $\alpha(2,6)$-Gal linkages of sialic acid on host cells. DAS181 is administered

225 as an inhalable dry powder to deliver sialidase to the pulmonary epithelium for cleavage of sialic acids,

226 which renders the cells inaccessible to infection by virus [80]. DAS181 was demonstrated to have broad-

227 spectrum activity, given the conserved nature of influenza and parainfluenza viruses binding to

228 respiratory epithelium. Preclinical in vitro and in vivo studies demonstrated that DAS181 has activity

229 against a number of seasonal influenza strains including those containing the H274Y mutation

230 (conferring resistance to oseltamivir), highly pathogenic avian influenza strains (H5N1), and pandemic

2312009 influenza A (H1N1). This compound was assessed in different Phase I and Phase II clinical trials

232 (NCT 00527865, NCT 01651494, NCT01037205) with results indicating a significant reduction of viral

233 load in treated influenza patients [88] but with identification of respiratory adverse events and rapid

234 clearance of the drug being consistent with the induction of antibodies against DAS-181 - this could be

235 a limitation in the duration and dosages of such treatment [163]. Other approaches targeting viral entry

236 have also been described (Table 5), e.g. targeting the endosome acidification step by inhibition of V-

237 ATPase (ex: bafilomycin A1, concanamycin), or inhibition of the internalization (ex: Dynasore) or

238 cleavage steps of haemagglutinin (ex: camostat). Most of these strategies were primarily evaluated at

239 the preclinical stage and have not been further evaluated as their efficacy was either limited or

240 accompanied by cytotoxicity. One exception is the protease inhibitor aprotinin, which was approved as

241 anti-influenza drug in Russia [169].

242 The step of nuclear import of vRNPs is a crucial one, for which there are today very few molecules

243 with antiviral potential described in literature. Interestingly, it has been shown in vitro that ivermectin

244 (Table 5), a well-known anti-parasite drug, was able to inhibit viral replication via inhibition of 245 importins (IMP $\alpha / \beta)$, and therefore the nuclear import of vRNPs [47].

247 Targeting the replication stage of the virus is one of the earliest host-targeting strategies, with pioneer

248 works on the antiviral efficacy of ribavirin in the 1970s [38]. However, this nucleoside analogue or its 
prodrug, less toxic, do not appear to be options being considered for the treatment of influenza virus infections. of influenza viruses, despite interesting preliminary in vitro and in vivo results [125]. (Table

251 5). Other, more recent strategies propose to target mRNA splicing. Influenza viruses are known to hijack cellular splicing machinery to their benefit, making them extremely dependent on it $[36,37]$. Several studies show that the inhibition of Cdc2-like kinase 1 (CLK1), involved in the alternative splicing of M2 gene of influenza, appears to be an interesting antiviral option, with several molecules available (TG003, Clypearin, Corilagin, Table 5). Of all its molecules, Clypearin has relatively low EC50s and very low toxicity, making it an attractive potential antiviral candidate. $[65,171]$.

While strategies to prevent the nuclear import of vRNPs are relatively uncommon, paradoxically there are many more therapeutic approaches to block the nuclear-cytoplasmic transport of vRNPs. Indeed, in contrast to the inhibition of importins, the inhibition of exportin 1 (XPO1) by Verdinexor (XPO1 antagonist KPT-335) allows to significantly reduce viral production in vitro and in vivo [101]. Another compound, DP2392-E10, inhibits nuclear export of both viral NP and nuclear export protein (NEP). More specifically, in vitro pull-down assays revealed that DP2392-E10 directly binds cellular CRM1, which mediates nuclear export of NP and NEP - highlighting CRM1 as a target of interest [19]. With the same objective, other strategies consist to target the Raf/MEK/ERK signaling pathway, known to be involved in the export of vRNPs [120]. Several MEK inhibitor molecules have been studied for their ability to inhibit the replication of influenza viruses, such as CI-1040 or U0126 [24, 108]. Interestingly,

267 Schräder and colleagues have demonstrated that Trametinib (GSK-1120212), a licensed MEK inhibitor 268 used for the treatment of malignant melanoma, efficiently blocks influenza viral replication of different 269 subtypes in vitro and in vivo [119] (Table 5).

270 Apical transport and budding, the last part of the last major step of the replication cycle is also the 271 object of several antiviral strategies, notably by blocking the transport of viral proteins to the plasma membrane (ex: Clonidine; [82]), or the cholesterol pathway, which would reduce virion egress.

273 (U18666A; [92]). One of the most advanced strategies is Nitazoxanide, initially licensed for the 274 treatment of parasitic infections, for which anti- influenza properties were first documented by 275 Rossignol et al. [113]. Interestingly, the proposed mode of action of nitazoxanide toward influenza is 276 clearly distinct to that for which it was designed in its initial indication, acting at the post-translational 
level by selectively blocking the maturation of the viral glycoprotein HA, with a consecutive impact on

278 its intracellular trafficking and insertion into the host plasma membrane [112]. This drug presents potent 279 antiviral activity against a large panel of circulating strains [139]. The effectiveness of nitazoxanide in 280 treating patients with non-complicated influenza was successful in a Phase IIb/III trial [50] and is 281 currently being assessed in a Phase III clinical trial (NCT01610245).

3.2 Drugs targeting host cell signaling pathways and host-response that are crucial for influenza replication cycle.

Our increased knowledge of signaling pathways that are crucial in the response to infection and/or those hijacked by the virus has allowed many research teams to explore complementary antiviral strategies that can be described here (Table 6). The targeting of the ref/MEK/ERK channel, mentioned above, could of course also have been listed here. At the crossroads of the regulatory pathways of the immune response and the stress response, the NF-kB pathway was one of the first to be studied (Table 6). In the context of cell biology approaches, it was initially shown that the anti-inflammatory drug acetylsalicylic acid (ASA) had interesting antiviral effect against influenza viruses in vitro and in vivo, via inhibition of the NF-kB activating IkkB kinase [83, 153, 159]. Several drugs targeting the NF-kB pathway have been evaluated since then, such as pyrrolidine dithiocarbamate or SC7574; with encouraging in vivo results $[39,49,149]$. BAY81-8781/LASAG (D, L-Lysine acetylsalicylate-glycine) (Table 6), a modified version of ASA demonstrates antiviral activity against several human and avian influenza viruses in vitro. In a mouse infection model, inhalation of LASAG resulted in reduced lung viral titers and protection of mice from lethal infection [35]. More recently, a Phase II proof-of-concept study comparing LASAG versus placebo in patients with severe influenza demonstrated that aerosolized LASAG improved the time to symptom alleviation compared to placebo, despite the absence of a statistically significant reduction of viral load in LASAG-treated group [116].

301 Based on clinical observations, hydroxyl methylglutaryl-coenzyme A (HMG-CoA) reductase inhibitors 302 such as statins (Table 6), approved for their use as cholesterol metabolism regulators, have demonstrated 303 pleiotropic anti-inflammatory and immunomodulatory properties, which could be of benefit to improve 304 survival of patients with severe influenza $[43,85]$. However, most in vivo studies reported so far failed 
to clearly demonstrate such a beneficial effect in the specific context of influenza infection $[6,72,115]$.

306 On the other hand, a few observational studies highlighted an association between statin treatment with 307 a reduction of mortality in patients hospitalized with laboratory-confirmed seasonal influenza [40, 142]. 308 A randomized placebo-controlled Phase II clinical trial (NCT02056340) aimed at evaluating the 309 potential effect of atorvastatin to reduce the severity of illness in influenza-infected patients is currently 310 undergoing. The combination of naproxen with clarithromycin and oseltamivir twice daily reduced the 311 both 30- and 90-day mortality and length of hospital stay of patients hospitalized for A(H3N2) influenza 312 [54]. Other approaches, at the preclinical validation stages, propose to target the TNF-alpha 313 (Etanercept);) or NOX2 (Apocynin/Ebselen) or lipoxygenase/COX pathway (Celecoxib/Mesalazine) 314 pathways $[12,28,74,97,124,157,167]$. A phase III clinical trial is currently investigating the benefit of celecoxib for the treatment of severe influenza (NCT02108366). These molecules could be of interest 316 to better control the inflammatory response, which is a very important aspect of the pathology.

317 Modulation of immune and inflammatory responses is a therapeutic avenue that has been much 318 explored, but which may present risks given the ambivalent aspect of these pathways in relation to viral 319 replication and the evolution of the pathology. Indeed, such treatment should stimulate induction of 320 antiviral genes to control IAV spread, without driving immunopathology. In this context, IFN-lambda 321 (Table 6) appears as a potent anti-influenza therapeutic, without the inflammatory side effects of IFN322 alpha treatment [29]. Intranasal administration of IFN- $\lambda 2 / 3$ was shown to significantly suppress 323 infection of various influenza strains, including WS/33 (H1N1), PR (H1N1), and H5N1 in the mouse 324 lung, and was accompanied by greater up-regulation of ISGs [67]. More recently, using a transcriptome325 based screening approaches, we identified and validated diltiazem, a calcium channel blocker used as 326 an anti-hypertensive drug, as a very promising host-targeted inhibitor of influenza infection. 327 Interestingly, the study of the mode of action revealed that diltiazem was a strong induced or type III 328 IFN [107]. An ongoing French multicenter randomized clinical trial is investigating the effect of 329 diltiazem- oseltamivir bi-therapy compared with standard oseltamivir monotherapy for the treatment of 330 severe influenza infections in intensive care units (FLUNEXT trial NCT03212716). 


\section{Perspectives and concluding remarks}

334 Among all the molecules listed in this chapter, some are already available on the market for other 335 therapeutic indications and fall within the scope of drug repurposing. This is the case for naproxen, 336 diltiazem, LASAG or Nitazoxanide, for example. The basis of drug repurposing relies on bypassing the 337 long, risky and expensive preclinical an early clinical evaluation stage conventionally used for de novo 338 drug development and exploiting available extensive human clinical, pharmacokinetics and safety data 339 as the starting point for the development [106] All these aspects make the repositioning of drugs a very 340 interesting approach, in particular to enable a rapid response to the need for new antiviral strategies in 341 the context of the emergence of a virus with pandemic potential.

342 Another very interesting perspective is the interest in combining different antiviral approaches with each 343 other, including classical approaches targeting the virus with those targeting the host cell. The concept 344 of combining therapies has already been used successfully, notably in the design of antiretroviral 345 treatments [13]. Combination therapy can have several objectives, such as reducing the risk of the 346 emergence of resistance by simultaneously targeting several viral proteins and/or key host factors, but 347 also increasing the effectiveness of the treatments by obtaining additive or synergistic effects.

348 While there is relatively little convincing evidence to support the use of conventional virus-targeting 349 antivirals in combination [41, 103], there are interestingly a growing number of examples of 350 combinations of combination host-targeted approaches with oseltamivir. For example, we have shown 351 that the combination of diltiazem and oseltamivir provides a much greater reduction in viral titers in a 352 reconstructed human epithelium model compared to single treatments [107]. More recently Schloer and 353 colleagues have shown that a combination treatment of an antifungal molecule, itraconazole, with 354 oseltamivir, achieves much greater antiviral activity compared to monotherapy, making it possible to 355 consider reducing the concentrations of drugs used, and thus possibly reducing the problems of adverse 356 effects and emergence of resistance mutations [117]. These results open up interesting prospects for the 357 development of future therapeutic strategies, particularly for the treatment of severe forms of influenza.

358 The potential arsenal for fighting influenza virus infections is potentially very extensive, in particular 359 thanks to the combination of new molecules targeting the virus, resulting from docking and structure360 based design strategies, with approaches targeting cellular factors and signaling pathways. In this 
361 context, the quality and relevance of the preclinical models, as well as the quality of the tools for

362 evaluating combinations of molecules, are important critical elements.

363 Beyond influenza viruses, many of the antiviral molecules described in this chapter have the potential

364 for broader-spectrum use. Indeed, some virus-targeted strategies can target viral determinants with very

365 strong similarities between different viruses. This is particularly the case with Naproxen for which we

366 have previously demonstrated antiviral activity against both influenza viruses and SARS-CoV-2 [73,

367 135]. This property is explained by the fact that the nucleoproteins $\mathrm{N}$ of enveloped, positive-sense,

368 single-stranded viruses Coronavirus $(\mathrm{CoV})$ share with negative-sense single-stranded viruses such as

369 Influenza A virus the ability to bind to- and protect genomic viral RNA without sequence specificity

370 and to form self-associated oligomers. Despite their differences, viruses induce and divert many

371 common cellular pathways. As a result, host-targeted approaches can identify molecules with a broad

372 spectrum of antiviral activity. An example is diltiazem, for which we have shown antiviral activity

373 against influenza viruses [107], but which has been shown to be effective against other respiratory

374 viruses, such as SARS-CoV-2 [104, 105], due to its mode of action involving the type III interferon

375 response. Efforts to identify anti-influenza molecules therefore open up very interesting prospects for

376 the broader development of antivirals. In many ways, antiviral research on influenza viruses is

377 pioneering in this area and provides a starting point for the study of other emerging viruses. 


\section{References}

381 Influenza (seasonal). World Health Organization. Available online at :http//www/cho.int/fact-

sheets/details/influenza- (seasonal) (accessed July 18, 2020).

1. Ai W, Zhang J, Zalloum WA et al. (2020) Discovery of novel "Dual-site" binding oseltamivir derivatives as potent influenza virus neuraminidase inhibitors. Eur J Med Chem 191:112147

2. Antanasijevic A, Durst MA, Cheng H et al. (2020) Structure of avian influenza hemagglutinin in complex with a small molecule entry inhibitor. Life Sci Alliance 3

3. Arranz R, Coloma R, Chichon FJ et al. (2012) The structure of native influenza virion ribonucleoproteins. Science 338:1634-1637

4. Bangaru S, Lang S, Schotsaert M et al. (2019) A Site of Vulnerability on the Influenza Virus Hemagglutinin Head Domain Trimer Interface. Cell 177:1136-1152 e1118

5. Basu A, Komazin-Meredith G, Mccarthy C et al. (2017) Molecular Mechanism Underlying the Action of Influenza A Virus Fusion Inhibitor MBX2546. ACS Infect Dis 3:330-335

6. Belser JA, Szretter KJ, Katz JM et al. (2013) Simvastatin and oseltamivir combination therapy does not improve the effectiveness of oseltamivir alone following highly pathogenic avian H5N1 influenza virus infection in mice. Virology 439:42-46

7. Bimbo LM, Denisova OV, Makila E et al. (2013) Inhibition of influenza A virus infection in vitro by saliphenylhalamide-loaded porous silicon nanoparticles. ACS Nano 7:6884-6893

8. Blaising J, Polyak SJ, Pecheur EI (2014) Arbidol as a broad-spectrum antiviral: an update. Antiviral Res 107:84-94

9. Byrn RA, Jones SM, Bennett HB et al. (2015) Preclinical activity of VX-787, a first-inclass, orally bioavailable inhibitor of the influenza virus polymerase PB2 subunit. Antimicrob Agents Chemother 59:1569-1582

10. Cady SD, Schmidt-Rohr K, Wang J et al. (2010) Structure of the amantadine binding site of influenza M2 proton channels in lipid bilayers. Nature 463:689-692

11. Carcelli M, Rogolino D, Gatti A et al. (2016) N-acylhydrazone inhibitors of influenza virus PA endonuclease with versatile metal binding modes. Sci Rep 6:31500

12. Carey MA, Bradbury JA, Rebolloso YD et al. (2010) Pharmacologic inhibition of COX1 and COX-2 in influenza A viral infection in mice. PloS One 5:e11610

13. Chaudhuri S, Symons JA, Deval J (2018) Innovation and trends in the development and approval of antiviral medicines: 1987-2017 and beyond. Antiviral Res. 155:76-88

14. Chen HW, Cheng JX, Liu MT et al. (2013) Inhibitory and combinatorial effect of diphyllin, a v-ATPase blocker, on influenza viruses. Antiviral Res 99:371-382

15. Chenavas S, Crepin T, Delmas B et al. (2013) Influenza virus nucleoprotein: structure, RNA binding, oligomerization and antiviral drug target. Future Microbiol 8:1537-1545

16. Chenavas S, Estrozi LF, Slama-Schwok A et al. (2013) Monomeric nucleoprotein of influenza A virus. PLoS Pathog 9:e1003275

17. Cho JH, Zhao B, Shi J et al. (2020) Molecular recognition of a host protein by NS1 of pandemic and seasonal influenza A viruses. Proc Natl Acad Sci U S A 117:6550-6558

18. Choi MS, Heo J, Yi CM et al. (2016) A novel p38 mitogen activated protein kinase (MAPK) specific inhibitor suppresses respiratory syncytial virus and influenza A virus 
replication by inhibiting virus-induced p38 MAPK activation. Biochem Biophys Res Commun 477:311-316

19. Chutiwitoonchai N, Mano T, Kakisaka M et al. (2017) Inhibition of CRM1-mediated nuclear export of influenza A nucleoprotein and nuclear export protein as a novel target for antiviral drug development. Virology 507:32-39

20. Clark MP, Ledeboer MW, Davies I et al. (2014) Discovery of a novel, first-in-class, orally bioavailable azaindole inhibitor (VX-787) of influenza PB2. J Med Chem 57:6668-6678

21. Collins PJ, Haire LF, Lin YP et al. (2008) Crystal structures of oseltamivir-resistant influenza virus neuraminidase mutants. Nature 453:1258-1261

22. Coloma R, Arranz R, De La Rosa-Trevin JM et al. (2020) Structural insights into influenza A virus ribonucleoproteins reveal a processive helical track as transcription mechanism. Nat Microbiol 5:727-734

23. Coloma R, Valpuesta JM, Arranz R et al. (2009) The structure of a biologically active influenza virus ribonucleoprotein complex. PLoS Pathog 5:e1000491

24. Courtin N, Fotso AF, Fautrad P et al. (2017) Antiviral activity of formyl peptide receptor 2 antagonists against influenza viruses. Antiviral Res. 143:252-261

25. Credille CV, Morrison CN, Stokes RW et al. (2019) SAR Exploration of Tight-Binding Inhibitors of Influenza Virus PA Endonuclease. J Med Chem 62:9438-9449

26. Crepin T, Dias A, Palencia A et al. (2010) Mutational and metal binding analysis of the endonuclease domain of the influenza virus polymerase PA subunit. J Virol 84:90969104

27. D'agostino I, Giacchello I, Nannetti G et al. (2018) Synthesis and biological evaluation of a library of hybrid derivatives as inhibitors of influenza virus PA-PB1 interaction. Eur J Med Chem 157:743-758

28. Davidson S (2018) Treating Influenza Infection, From Now and Into the Future. Frontiers in Immunology 9:1946

29. Davidson S, Mccabe TM, Crotta S et al. (2016) IFN $\lambda$ is a potent anti-influenza therapeutic without the inflammatory side effects of IFN $\alpha$ treatment. EMBO Mol Med 8:1099-1112

30. De Vries E, Tscherne DM, Wienholts MJ et al. (2011) Dissection of the influenza A virus endocytic routes reveals macropinocytosis as an alternative entry pathway. PLoS Pathog 7:e1001329

31. Desantis J, Nannetti G, Massari S et al. (2017) Exploring the cycloheptathiophene-3carboxamide scaffold to disrupt the interactions of the influenza polymerase subunits and obtain potent anti-influenza activity. Eur J Med Chem 138:128-139

32. Dias A, Bouvier D, Crepin T et al. (2009) The cap-snatching endonuclease of influenza virus polymerase resides in the PA subunit. Nature 458:914-918

33. Dilly S, Fotso Fotso A, Lejal N et al. (2018) From Naproxen Repurposing to Naproxen Analogues and Their Antiviral Activity against Influenza A Virus. J Med Chem 61:7202-7217

34. Dong G, Peng C, Luo J et al. (2015) Adamantane-resistant influenza a viruses in the world (1902-2013): frequency and distribution of M2 gene mutations. PLoS One 10:e0119115

35. Droebner K, Haasbach E, Dudek SE et al. (2017) Pharmacodynamics, Pharmacokinetics, and Antiviral Activity of BAY 81-8781, a Novel NF-kappaB Inhibiting Anti-influenza Drug. Front Microbiol 8:2130

36. Dubois J, Terrier O, Rosa-Calatrava M (2014) Influenza viruses and mRNA splicing: doing more with less. mBio 5:e00070-00014 
37. Dubois J, Traversier A, Julien T et al. (2019) The Nonstructural NS1 Protein of Influenza Viruses Modulates TP53 Splicing through Host Factor CPSF4. J. Virol. 93

38. Durr FE, Lindh HF, Forbes M (1975) Efficacy of 1-beta-D-ribofuranosyl-1,2,4-triazole3-carboxamide against influenza virus infections in mice. Antimicrob. Agents Chemother. 7:582-586

39. Ehrhardt C, Rückle A, Hrincius ER et al. (2013) The NF- $\kappa B$ inhibitor SC75741 efficiently blocks influenza virus propagation and confers a high barrier for development of viral resistance. Cell. Microbiol. 15:1198-1211

40. Enserink M (2005) Infectious disease. Old drugs losing effectiveness against flu; could statins fill gap? Science (New York, N.Y.) 309:1976-1977

41. Escuret V, Cornu C, Boutitie F et al. (2012) Oseltamivir-zanamivir bitherapy compared to oseltamivir monotherapy in the treatment of pandemic 2009 influenza A(H1N1) virus infections. Antiviral Res. 96:130-137

42. Fan H, Walker AP, Carrique L et al. (2019) Structures of influenza A virus RNA polymerase offer insight into viral genome replication. Nature 573:287-290

43. Fedson DS (2013) Treating influenza with statins and other immunomodulatory agents. Antiviral Res. 99:417-435

44. Fodor E, Te Velthuis AJW (2019) Structure and Function of the Influenza Virus Transcription and Replication Machinery. Cold Spring Harb Perspect Med

45. Gaisina IN, Peet NP, Cheng H et al. (2020) Optimization of 4-Aminopiperidines as Inhibitors of Influenza A Viral Entry That Are Synergistic with Oseltamivir. J Med Chem 63:3120-3130

46. Gerritz SW, Cianci C, Kim S et al. (2011) Inhibition of influenza virus replication via small molecules that induce the formation of higher-order nucleoprotein oligomers. Proc Natl Acad Sci U S A 108:15366-15371

47. Götz V, Magar L, Dornfeld D et al. (2016) Influenza A viruses escape from MxA restriction at the expense of efficient nuclear vRNP import. Scientific Reports 6:23138

48. Guilligay D, Tarendeau F, Resa-Infante P et al. (2008) The structural basis for cap binding by influenza virus polymerase subunit PB2. Nat Struct Mol Biol 15:500-506

49. Haasbach E, Reiling SJ, Ehrhardt C et al. (2013) The NF-kappaB inhibitor SC75741 protects mice against highly pathogenic avian influenza A virus. Antiviral Res. 99:336344

50. Haffizulla J, Hartman A, Hoppers M et al. (2014) Effect of nitazoxanide in adults and adolescents with acute uncomplicated influenza: a double-blind, randomised, placebocontrolled, phase $2 \mathrm{~b} / 3$ trial. The Lancet. Infectious Diseases 14:609-618

51. Harada S, Yokomizo K, Monde K et al. (2007) A broad antiviral neutral glycolipid, fattiviracin FV-8, is a membrane fluidity modulator. Cell Microbiol 9:196-203

52. Hu F, Luo W, Hong M (2010) Mechanisms of proton conduction and gating in influenza M2 proton channels from solid-state NMR. Science 330:505-508

53. Hu Y, Zhang J, Musharrafieh RG et al. (2017) Discovery of dapivirine, a nonnucleoside HIV-1 reverse transcriptase inhibitor, as a broad-spectrum antiviral against both influenza A and B viruses. Antiviral Res 145:103-113

54. Hung IFN, To KKW, Chan JFW et al. (2017) Efficacy of Clarithromycin-NaproxenOseltamivir Combination in the Treatment of Patients Hospitalized for Influenza A(H3N2) Infection: An Open-label Randomized, Controlled, Phase IIb/III Trial. Chest 151:1069-1080

55. Hussein AFA, Cheng H, Tundup S et al. (2020) Identification of entry inhibitors with 4-aminopiperidine scaffold targeting group 1 influenza A virus. Antiviral Res 177:104782 
56. Iuliano AD, Roguski KM, Chang HH et al. (2018) Estimates of global seasonal influenza-associated respiratory mortality: a modelling study. Lancet (London, England) 391:1285-1300

57. Jalily PH, Duncan MC, Fedida D et al. (2020) Put a cork in it: Plugging the M2 viral ion channel to sink influenza. Antiviral Res 178:104780

58. Jia R, Zhang J, Ai W et al. (2019) Design, synthesis and biological evaluation of "MultiSite"-binding influenza virus neuraminidase inhibitors. Eur J Med Chem 178:64-80

59. Jones JC, Kumar G, Barman S et al. (2018) Identification of the I38T PA Substitution as a Resistance Marker for Next-Generation Influenza Virus Endonuclease Inhibitors. mBio 9

60. Ju H, Xiu S, Ding X et al. (2020) Discovery of novel 1,2,3-triazole oseltamivir derivatives as potent influenza neuraminidase inhibitors targeting the 430 -cavity. Eur $\mathrm{J}$ Med Chem 187:111940

61. Ju H, Zhan P, Liu X (2019) Designing influenza polymerase acidic endonuclease inhibitors via 'privileged scaffold' re-evolution/refining strategy. Future Med Chem

62. Ju H, Zhang J, Huang B et al. (2017) Inhibitors of Influenza Virus Polymerase Acidic (PA) Endonuclease: Contemporary Developments and Perspectives. J Med Chem 60:3533-3551

63. Kadam RU, Wilson IA (2017) Structural basis of influenza virus fusion inhibition by the antiviral drug Arbidol. Proc Natl Acad Sci U S A 114:206-214

64. Kao RY, Yang D, Lau LS et al. (2010) Identification of influenza A nucleoprotein as an antiviral target. Nat Biotechnol 28:600-605

65. Karlas A, Machuy N, Shin Y et al. (2010) Genome-wide RNAi screen identifies human host factors crucial for influenza virus replication. Nature 463:818-822

66. Kim JI, Lee S, Lee GY et al. (2019) Novel Small Molecule Targeting the Hemagglutinin Stalk of Influenza Viruses. J Virol 93

67. Kim S, Kim M-J, Kim C-H et al. (2017) The Superiority of IFN- $\lambda$ as a Therapeutic Candidate to Control Acute Influenza Viral Lung Infection. Am. J. Respir. Cell Mol. Biol. 56:202-212

68. Kleinpeter AB, Jureka AS, Falahat SM et al. (2018) Structural analyses reveal the mechanism of inhibition of influenza virus NS1 by two antiviral compounds. J Biol Chem 293:14659-14668

69. König R, Stertz S, Zhou Y et al. (2010) Human host factors required for influenza virus replication. Nature 463:813-817

70. Kowalinski E, Zubieta C, Wolkerstorfer A et al. (2012) Structural analysis of specific metal chelating inhibitor binding to the endonuclease domain of influenza pH1N1 (2009) polymerase. PLoS Pathog 8:e1002831

71. Krammer F, Smith GJD, Fouchier RaM et al. (2018) Influenza. Nat Rev Dis Primers $4: 3$

72. Kumaki Y, Morrey JD, Barnard DL (2012) Effect of statin treatments on highly pathogenic avian influenza H5N1, seasonal and H1N1pdm09 virus infections in BALB/c mice. Future Virol 7:801-818

73. Lejal N, Tarus B, Bouguyon E et al. (2013) Structure-based discovery of the novel antiviral properties of naproxen against the nucleoprotein of influenza A virus. Antimicrob Agents Chemother 57:2231-2242

74. Lejal N, Truchet S, Bechor E et al. (2018) Turning off NADPH oxidase-2 by impeding p67(phox) activation in infected mouse macrophages reduced viral entry and inflammation. Biochim Biophys Acta Gen Subj 1862:1263-1275

75. Li P, Du R, Wang Y et al. (2020) Identification of Chebulinic Acid and Chebulagic Acid as Novel Influenza Viral Neuraminidase Inhibitors. Front Microbiol 11:182 
601

602

603

604

605

606

607

608

609

610

76. Liu Q, Zhou YH, Yang ZQ (2016) The cytokine storm of severe influenza and development of immunomodulatory therapy. Cell Mol Immunol 13:3-10

77. Liu T, Liu M, Chen F et al. (2018) A Small-Molecule Compound Has Anti-influenza A Virus Activity by Acting as a "PB2 Inhibitor". Mol Pharm 15:4110-4120

78. Lo CY, Li OT, Tang WP et al. (2018) Identification of influenza polymerase inhibitors targeting C-terminal domain of PA through surface plasmon resonance screening. Sci Rep 8:2280

79. Makau JN, Watanabe K, Ishikawa T et al. (2017) Identification of small molecule inhibitors for influenza a virus using in silico and in vitro approaches. PLoS One 12:e0173582

80. Malakhov MP, Aschenbrenner LM, Smee DF et al. (2006) Sialidase fusion protein as a novel broad-spectrum inhibitor of influenza virus infection. Antimicrob. Agents Chemother. 50:1470-1479

81. Massari S, Goracci L, Desantis J et al. (2016) Polymerase Acidic Protein-Basic Protein 1 (PA-PB1) Protein-Protein Interaction as a Target for Next-Generation Anti-influenza Therapeutics. J Med Chem 59:7699-7718

82. Matsui K, Ozawa M, Kiso M et al. (2018) Stimulation of alpha2-adrenergic receptors impairs influenza virus infection. Scientific Reports 8:4631

83. Mazur I, Wurzer WJ, Ehrhardt C et al. (2007) Acetylsalicylic acid (ASA) blocks influenza virus propagation via its NF-kappaB-inhibiting activity. Cell. Microbiol. 9:1683-1694

84. Mcgowan DC, Balemans W, Embrechts W et al. (2019) Design, Synthesis, and Biological Evaluation of Novel Indoles Targeting the Influenza PB2 Cap Binding Region. J Med Chem 62:9680-9690

85. Mehrbod P, Omar AR, Hair-Bejo M et al. (2014) Mechanisms of action and efficacy of statins against influenza. Biomed Res Int 2014:872370

86. Meliopoulos VA, Andersen LE, Birrer KF et al. (2012) Host gene targets for novel influenza therapies elucidated by high-throughput RNA interference screens. FASEB J. 26:1372-1386

87. Monod A, Swale C, Tarus B et al. (2015) Learning from structure-based drug design and new antivirals targeting the ribonucleoprotein complex for the treatment of influenza. Expert Opin Drug Discov 10:345-371

88. Moss RB, Hansen C, Sanders RL et al. (2012) A phase II study of DAS181, a novel host directed antiviral for the treatment of influenza infection. J. Infect. Dis. 206:18441851

89. Mould JA, Li HC, Dudlak CS et al. (2000) Mechanism for proton conduction of the $\mathrm{M}(2)$ ion channel of influenza A virus. J Biol Chem 275:8592-8599

90. Muller KH, Kainov DE, El Bakkouri K et al. (2011) The proton translocation domain of cellular vacuolar ATPase provides a target for the treatment of influenza A virus infections. Br J Pharmacol 164:344-357

91. Musharrafieh R, Ma C, Wang J (2020) Discovery of M2 channel blockers targeting the drug-resistant double mutants M2-S31N/L26I and M2-S31N/V27A from the influenza A viruses. Eur J Pharm Sci 141:105124

92. Musiol A, Gran S, Ehrhardt C et al. (2013) Annexin A6-balanced late endosomal cholesterol controls influenza A replication and propagation. mBio 4:e00608-00613

93. Nacken W, Ehrhardt C, Ludwig S (2012) Small molecule inhibitors of the c-Jun Nterminal kinase (JNK) possess antiviral activity against highly pathogenic avian and human pandemic influenza A viruses. Biol Chem 393:525-534

94. Nannetti G, Massari S, Mercorelli B et al. (2019) Potent and broad-spectrum cycloheptathiophene-3-carboxamide compounds that target the PA-PB1 interaction of 
influenza virus RNA polymerase and possess a high barrier to drug resistance. Antiviral Res 165:55-64

95. Obayashi E, Yoshida H, Kawai F et al. (2008) The structural basis for an essential subunit interaction in influenza virus RNA polymerase. Nature 454:1127-1131

96. Omoto S, Speranzini V, Hashimoto T et al. (2018) Characterization of influenza virus variants induced by treatment with the endonuclease inhibitor baloxavir marboxil. Sci Rep 8:9633

97. Oostwoud LC, Gunasinghe P, Seow HJ et al. (2016) Apocynin and ebselen reduce influenza A virus-induced lung inflammation in cigarette smoke-exposed mice. Scientific Reports 6:20983

98. Pang B, Cheung NN, Zhang W et al. (2016) Structural Characterization of H1N1 Nucleoprotein-Nucleozin Binding Sites. Sci Rep 6:29684

99. Patnaik S, Basu D, Southall N et al. (2019) Identification, design and synthesis of novel pyrazolopyridine influenza virus nonstructural protein 1 antagonists. Bioorg Med Chem Lett 29:1113-1119

100. Pautus S, Sehr P, Lewis J et al. (2013) New 7-methylguanine derivatives targeting the influenza polymerase PB2 cap-binding domain. J Med Chem 56:8915-8930

101. Perwitasari O, Johnson S, Yan X et al. (2014) Verdinexor, a novel selective inhibitor of nuclear export, reduces influenza a virus replication in vitro and in vivo. J. Virol. 88:10228-10243

102. Pflug A, Guilligay D, Reich S et al. (2014) Structure of influenza A polymerase bound to the viral RNA promoter. Nature 516:355-360

103. Pizzorno A, Abed Y, Rhéaume C et al. (2014) Oseltamivir-zanamivir combination therapy is not superior to zanamivir monotherapy in mice infected with influenza A(H3N2) and A(H1N1)pdm09 viruses. Antiviral Res. 105:54-58

104. Pizzorno A, Padey B, Dubois J et al. (2020) In vitro evaluation of antiviral activity of single and combined repurposable drugs against SARS-CoV-2. Antiviral Res.:104878

105. Pizzorno A, Padey B, Julien T et al. (2020) Characterization and treatment of SARSCoV-2 in nasal and bronchial human airway epithelia. bioRxiv:2020.2003.2031.017889

106. Pizzorno A, Padey B, Terrier O et al. (2019) Drug Repurposing Approaches for the Treatment of Influenza Viral Infection: Reviving Old Drugs to Fight Against a LongLived Enemy. Frontiers in Immunology 10:531

107. Pizzorno A, Terrier O, Nicolas De Lamballerie C et al. (2019) Repurposing of Drugs as Novel Influenza Inhibitors From Clinical Gene Expression Infection Signatures. Frontiers in Immunology 10:60

108. Pleschka S, Wolff T, Ehrhardt $C$ et al. (2001) Influenza virus propagation is impaired by inhibition of the Raf/MEK/ERK signalling cascade. Nat. Cell Biol. 3:301-305

109. Powell JD, Waters KM (2017) Influenza-Omics and the Host Response: Recent Advances and Future Prospects. Pathogens 6

110. Reich S, Guilligay D, Pflug A et al. (2014) Structural insight into cap-snatching and RNA synthesis by influenza polymerase. Nature 516:361-366

111. Robb NC, Te Velthuis AJW, Fodor E et al. (2019) Real-time analysis of single influenza virus replication complexes reveals large promoter-dependent differences in initiation dynamics. Nucleic Acids Res 47:6466-6477

112. Rossignol J-F (2014) Nitazoxanide: a first-in-class broad-spectrum antiviral agent. Antiviral Res. 110:94-103

113. Rossignol JF, La Frazia S, Chiappa L et al. (2009) Thiazolides, a new class of antiinfluenza molecules targeting viral hemagglutinin at the post-translational level. J. Biol. Chem. 284:29798-29808 
114. Russell RJ, Haire LF, Stevens DJ et al. (2006) The structure of H5N1 avian influenza neuraminidase suggests new opportunities for drug design. Nature 443:45-49

115. Salomon R, Hoffmann E, Webster RG (2007) Inhibition of the cytokine response does not protect against lethal H5N1 influenza infection. Proc. Natl. Acad. Sci. U.S.A. 104:12479-12481

116. Scheuch G, Canisius S, Nocker K et al. (2018) Targeting intracellular signaling as an antiviral strategy: aerosolized LASAG for the treatment of influenza in hospitalized patients. Emerging Microbes \& Infections 7:21

117. Schloer S, Goretzko J, Pleschka S et al. (2020) Combinatory Treatment with Oseltamivir and Itraconazole Targeting Both Virus and Host Factors in Influenza A Virus Infection. Viruses 12

118. Schnell JR, Chou JJ (2008) Structure and mechanism of the M2 proton channel of influenza A virus. Nature 451:591-595

119. Schräder T, Dudek SE, Schreiber A et al. (2018) The clinically approved MEK inhibitor Trametinib efficiently blocks influenza A virus propagation and cytokine expression. Antiviral Res. 157:80-92

120. Schreiber A, Boff L, Anhlan D et al. (2020) Dissecting the mechanism of signalingtriggered nuclear export of newly synthesized influenza virus ribonucleoprotein complexes. Proc. Natl. Acad. Sci. U.S.A. 117:16557-16566

121. Sharma M, Yi M, Dong H et al. (2010) Insight into the mechanism of the influenza A proton channel from a structure in a lipid bilayer. Science 330:509-512

122. Sheahan TP, Sims AC, Zhou S et al. (2020) An orally bioavailable broad-spectrum antiviral inhibits SARS-CoV-2 in human airway epithelial cell cultures and multiple coronaviruses in mice. Sci Transl Med 12

123. Shen YF, Chen YH, Chu SY et al. (2011) E339...R416 salt bridge of nucleoprotein as a feasible target for influenza virus inhibitors. Proc Natl Acad Sci U S A 108:1651516520

124. Shi X, Zhou W, Huang H et al. (2013) Inhibition of the inflammatory cytokine tumor necrosis factor-alpha with etanercept provides protection against lethal H1N1 influenza infection in mice. Crit Care 17:R301

125. Sidwell RW, Bailey KW, Wong MH et al. (2005) In vitro and in vivo influenza virusinhibitory effects of viramidine. Antiviral Res. 68:10-17

126. Slaine PD, Kleer M, Smith NK et al. (2017) Stress Granule-Inducing Eukaryotic Translation Initiation Factor 4A Inhibitors Block Influenza A Virus Replication. Viruses 9

127. Song MS, Kumar G, Shadrick WR et al. (2016) Identification and characterization of influenza variants resistant to a viral endonuclease inhibitor. Proc Natl Acad Sci U S A 113:3669-3674

128. Stertz S, Shaw ML (2011) Uncovering the global host cell requirements for influenza virus replication via RNAi screening. Microbes Infect. 13:516-525

129. Strauch EM, Bernard SM, La D et al. (2017) Computational design of trimeric influenza-neutralizing proteins targeting the hemagglutinin receptor binding site. Nat Biotechnol 35:667-671

130. Sugiyama K, Obayashi E, Kawaguchi A et al. (2009) Structural insight into the essential PB1-PB2 subunit contact of the influenza virus RNA polymerase. EMBO J 28:18031811

131. Swale C, Monod A, Tengo L et al. (2016) Structural characterization of recombinant IAV polymerase reveals a stable complex between viral PA-PB1 heterodimer and host RanBP5. Sci Rep 6:24727 
132. Tang Y, Zaitseva F, Lamb RA et al. (2002) The gate of the influenza virus M2 proton channel is formed by a single tryptophan residue. J Biol Chem 277:39880-39886

133. Tarus B, Bakowiez O, Chenavas S et al. (2012) Oligomerization paths of the nucleoprotein of influenza A virus. Biochimie 94:776-785

134. Tarus B, Bertrand H, Zedda G et al. (2015) Structure-based design of novel naproxen derivatives targeting monomeric nucleoprotein of Influenza A virus. J Biomol Struct Dyn 33:1899-1912

135. Terrier O, Dilly S, Pizzorno A et al. (2020) Broad-spectrum antiviral activity of naproxen: from Influenza $\mathrm{A}$ to SARS-CoV-2 Coronavirus. bioRxiv:2020.2004.2030.069922

136. Thomaston JL, Konstantinidi A, Liu L et al. (2020) X-ray Crystal Structures of the Influenza M2 Proton Channel Drug-Resistant V27A Mutant Bound to a SpiroAdamantyl Amine Inhibitor Reveal the Mechanism of Adamantane Resistance. Biochemistry 59:627-634

137. Thomaston JL, Polizzi NF, Konstantinidi A et al. (2018) Inhibitors of the M2 Proton Channel Engage and Disrupt Transmembrane Networks of Hydrogen-Bonded Waters. J Am Chem Soc 140:15219-15226

138. Thomaston JL, Wu Y, Polizzi N et al. (2019) X-ray Crystal Structure of the Influenza A M2 Proton Channel S31N Mutant in Two Conformational States: An Open and Shut Case. J Am Chem Soc 141:11481-11488

139. Tilmanis D, Van Baalen C, Oh DY et al. (2017) The susceptibility of circulating human influenza viruses to tizoxanide, the active metabolite of nitazoxanide. Antiviral Res. 147:142-148

140. Toots M, Yoon JJ, Hart M et al. (2020) Quantitative efficacy paradigms of the influenza clinical drug candidate EIDD-2801 in the ferret model. Transl Res 218:16-28

141. Van Dongen MJP, Kadam RU, Juraszek J et al. (2019) A small-molecule fusion inhibitor of influenza virus is orally active in mice. Science 363

142. Vandermeer ML, Thomas AR, Kamimoto L et al. (2012) Association between use of statins and mortality among patients hospitalized with laboratory-confirmed influenza virus infections: a multistate study. J. Infect. Dis. 205:13-19

143. Vidic J, Noiray M, Bagchi A et al. (2016) Identification of a Novel Complex between the Nucleoprotein and PA(1-27) of Influenza A Virus Polymerase. Biochemistry 55:4259-4262

144. Walker AP, Fodor E (2019) Interplay between Influenza Virus and the Host RNA Polymerase II Transcriptional Machinery. Trends Microbiol 27:398-407

145. Wandzik JM, Kouba T, Cusack S (2020) Structure and Function of Influenza Polymerase. Cold Spring Harb Perspect Med

146. Wandzik JM, Kouba T, Karuppasamy M et al. (2020) A Structure-Based Model for the Complete Transcription Cycle of Influenza Polymerase. Cell 181:877-893 e821

147. Wang Y, Ding Y, Yang C et al. (2017) Inhibition of the infectivity and inflammatory response of influenza virus by Arbidol hydrochloride in vitro and in vivo (mice and ferret). Biomed Pharmacother 91:393-401

148. Watanabe T, Kawaoka Y (2015) Influenza virus-host interactomes as a basis for antiviral drug development. Curr Opin Virol 14:71-78

149. Wiesener N, Zimmer C, Jarasch-Althof N et al. (2011) Therapy of experimental influenza virus infection with pyrrolidine dithiocarbamate. Med. Microbiol. Immunol. 200:115-126

150. Woodring JL, Lu SH, Krasnova L et al. (2020) Disrupting the Conserved Salt Bridge in the Trimerization of Influenza A Nucleoprotein. J Med Chem 63:205-215 
151. Wright ZVF, Wu NC, Kadam RU et al. (2017) Structure-based optimization and synthesis of antiviral drug Arbidol analogues with significantly improved affinity to influenza hemagglutinin. Bioorg Med Chem Lett 27:3744-3748

152. Wu G, Yu G, Yu Y et al. (2020) Chemoreactive-Inspired Discovery of Influenza A Virus Dual Inhibitor to Block Hemagglutinin-Mediated Adsorption and Membrane Fusion. J Med Chem 63:6924-6940

153. Wurzer WJ, Ehrhardt C, Pleschka S et al. (2004) NF-kappaB-dependent induction of tumor necrosis factor-related apoptosis-inducing ligand (TRAIL) and Fas/FasL is crucial for efficient influenza virus propagation. J. Biol. Chem. 279:30931-30937

154. Yamaya M, Shimotai Y, Hatachi Y et al. (2015) The serine protease inhibitor camostat inhibits influenza virus replication and cytokine production in primary cultures of human tracheal epithelial cells. Pulm Pharmacol Ther 33:66-74

155. Yao Y, Kadam RU, Lee CD et al. (2020) An influenza A hemagglutinin small-molecule fusion inhibitor identified by a new high-throughput fluorescence polarization screen. Proc Natl Acad Sci U S A

156. Ye Q, Krug RM, Tao YJ (2006) The mechanism by which influenza A virus nucleoprotein forms oligomers and binds RNA. Nature 444:1078-1082

157. Ye S, Lowther S, Stambas J (2015) Inhibition of reactive oxygen species production ameliorates inflammation induced by influenza A viruses via upregulation of SOCS1 and SOCS3. J. Virol. 89:2672-2683

158. Yeganeh B, Ghavami S, Kroeker AL et al. (2015) Suppression of influenza A virus replication in human lung epithelial cells by noncytotoxic concentrations bafilomycin A1. Am J Physiol Lung Cell Mol Physiol 308:L270-286

159. Yin MJ, Yamamoto Y, Gaynor RB (1998) The anti-inflammatory agents aspirin and salicylate inhibit the activity of I(kappa)B kinase-beta. Nature 396:77-80

160. Yoon JJ, Toots M, Lee S et al. (2018) Orally Efficacious Broad-Spectrum Ribonucleoside Analog Inhibitor of Influenza and Respiratory Syncytial Viruses. Antimicrob Agents Chemother 62

161. Yuan S, Chu H, Singh K et al. (2016) A novel small-molecule inhibitor of influenza A virus acts by suppressing PA endonuclease activity of the viral polymerase. Sci Rep 6:22880

162. Yuan S, Chu H, Ye J et al. (2017) Identification of a novel small-molecule compound targeting the influenza A virus polymerase PB1-PB2 interface. Antiviral Res 137:58-66

163. Zenilman JM, Fuchs EJ, Hendrix CW et al. (2015) Phase 1 clinical trials of DAS181, an inhaled sialidase, in healthy adults. Antiviral Res. 123:114-119

164. Zhang J, Hu Y, Foley C et al. (2018) Exploring Ugi-Azide Four-Component Reaction Products for Broad-Spectrum Influenza Antivirals with a High Genetic Barrier to Drug Resistance. Sci Rep 8:4653

165. Zhang J, Hu Y, Wu N et al. (2020) Discovery of Influenza Polymerase PA-PB1 Interaction Inhibitors Using an In Vitro Split-Luciferase Complementation-Based Assay. ACS Chem Biol 15:74-82

166. Zhang J, Poongavanam V, Kang D et al. (2018) Optimization of N-Substituted Oseltamivir Derivatives as Potent Inhibitors of Group-1 and -2 Influenza A Neuraminidases, Including a Drug-Resistant Variant. J Med Chem 61:6379-6397

167. Zheng B-J, Chan K-W, Lin Y-P et al. (2008) Delayed antiviral plus immunomodulator treatment still reduces mortality in mice infected by high inoculum of influenza A/H5N1 virus. Proc. Natl. Acad. Sci. U.S.A. 105:8091-8096

168. Zheng W, Fan W, Zhang S et al. (2019) Naproxen Exhibits Broad Anti-influenza Virus Activity in Mice by Impeding Viral Nucleoprotein Nuclear Export. Cell Rep 27:18751885 e 1875 
820 169. Zhirnov OP, Klenk HD, Wright PF (2011) Aprotinin and similar protease inhibitors as 821 drugs against influenza. Antiviral Res 92:27-36

822 170. Zhou Z, Liu T, Zhang J et al. (2018) Influenza A virus polymerase: an attractive target for next-generation anti-influenza therapeutics. Drug Discov Today 23:503-518

171. Zu M, Li C, Fang J-S et al. (2015) Drug Discovery of Host CLK1 Inhibitors for 826 Influenza Treatment. Molecules 20:19735-19747 
828 Figure 1. Influenza viral particle and viral cycle; current state of anti-influenza drug discovery

829 and development. (A) Influenza A virus (IAV) particle. The IAV genome is composed of eight 830 ribonucleoprotein complexes (vRNPs). Each one consists of single-stranded negative-sense viral RNA 831 (vRNA) encapsidated by viral nucleoprotein (NP) and a viral polymerase complex (PA, PB1, and PB2) 832 positioned at the extremity of the vRNA segment. Three viral proteins are embedded within the viral 833 membrane, hemagglutinin (HA), neuraminidase (NA), and ion channel protein (M2). Matrix protein 1 834 (M1) underlies the viral envelope and holds the vRNPs inside the virion. (B) The viral particle binds to 835 sialic acid receptors and enters the cell via receptor-mediated endocytosis. Acidification of the endocytic 836 vesicles leads to virus uncoating mediated by the M2 ion channel. vRNPs are then released into the 837 cytoplasm and transported into the nucleus. There, the viral RNA-dependent RNA polymerase complex 838 snatches the host mRNA caps to initiate the negative vRNA transcription. Transcribed vRNAs then need 839 to undergo an mRNA maturation phase, including the pre-mRNA splicing, before export to the 840 cytoplasm to be translated. vRNAs are also replicated in the nucleus to generate new vRNPs in 841 association with neosynthesized viral proteins. Progeny vRNPs are transported toward the cytoplasmic 842 membrane with viral components to be packaged into new infectious particles which are formed by 843 cellular envelope budding. Classic virus-targeting strategies are highlighted in red, and virus-host844 targeted strategies in blue. Figure created by BioRender.com

846 Figure 2: Looking down the M2 channel in the presence of inhibitors: Structure of M2 WT and VA27 847 mutant in complex with amantadine and spiroamantadine. View down the pore channel in A- WT848 amantadine (V27 is colored in yellow, PDB ID 6BKK[137]) and B- V27A-spiroamantadine complexes 849 (A27 is colored in yellow, PDB ID 6NV1[136])

\section{0}

Figure 3: Structures of the approved NA inhibitors

Figure 4: Structure of some of the pre-clinical candidates targeting HA: A: Structure of HA in

854 complex with JNJ4796 shown in orange (PDB ID 6CF7)[141] B: Structure of trimeric HA in complex 855 with mini-binder highlighted in yellow (PDB ID 6KUY)[129].

856 Figure 5: Structure of some of the pre-clinical candidates targeting the polymerase A: Active-site 857 PA N-terminal inhibitor compound 22[25]; B: PB2 inhibitor Pimodivir [20] (the numbering are 858 associated with this structure corresponding to the full-length PB2, C: nucleozin-NP oligomeric 859 complex PDB ID 5B7B, monomers A and B are in cyan and yellow, respectively; D: Naproxen F1-NP 860 monomeric complex from docking studies[33].

\section{Figure 6: Structures of the approved polymerase inhibitors and some pre-clinical candidates}




\section{Tables}

Table 1. Summary of the activity and structures of the main antiviral compounds bound to their target, the proton channel M2 of Influenza A or the neuraminidase NA of Influenza A and B.

\begin{tabular}{|c|c|c|c|c|c|}
\hline Target & Compound & $\mathrm{IC}_{50}$ & PDB ID & $\begin{array}{c}\text { Stage } \\
\text { (year approval) }\end{array}$ & references \\
\hline \multirow{3}{*}{ M2 } & Amantadine & $\begin{array}{l}100 \mu \mathrm{M}(\mathrm{H} 1 \mathrm{~N} 1 \mathrm{WT}) \\
>500 \mu \mathrm{M}(\mathrm{S} 31 \mathrm{~N}) \\
15.7 \mu \mathrm{M}\left(\mathrm{WT} \text { channel }^{\mathrm{a}}\right)[155]\end{array}$ & $6 \mathrm{BKK}$ & $\begin{array}{c}\text { Approved } \\
\text { (1976) }\end{array}$ & {$[137],[10]$} \\
\hline & Rimantadine & $\begin{array}{l}0.1 \mu \mathrm{M}(\mathrm{H} 1 \mathrm{~N} 1 \mathrm{WT}) \\
>200 \mu \mathrm{M}(\mathrm{S} 31 \mathrm{~N})\end{array}$ & $2 \mathrm{RLF}$ & $\begin{array}{l}\text { Approved } \\
\text { (1994) }\end{array}$ & [118] \\
\hline & Spiro-adamantyl amine & $\begin{array}{l}18.7 \mu \mathrm{M}\left(\mathrm{WT}_{\text {channel }}^{\mathrm{a}}\right) \\
0.2 \mu \mathrm{M}\left(\mathrm{V}^{2} 7 \mathrm{~A}^{\mathrm{a}}\right)\end{array}$ & $\begin{array}{l}6 \mathrm{BMZ} \\
6 \mathrm{NV} 1 \\
6 \mathrm{OUG}\end{array}$ & Pre-clinical & {$[136,137]$} \\
\hline \multirow{6}{*}{ NA } & Oseltamivir (Tamiflu) & $0.8 \mathrm{nM}(\mathrm{N} 5 \mathrm{NA})$ & $2 \mathrm{HT} 7$ & $\begin{array}{l}\text { Approved } \\
\text { (1999) }\end{array}$ & [114] \\
\hline & Peramivir & $3.4 \mathrm{nM}$ & $2 \mathrm{HTU}$ & $\begin{array}{l}\text { Approved } \\
\text { (2014) }\end{array}$ & [114] \\
\hline & Zanamivir & $0.6 \mathrm{nM}(\mathrm{N} 5 \mathrm{NA})$ & $3 \mathrm{CKZ}$ & $\begin{array}{l}\text { Approved } \\
\text { (1999) }\end{array}$ & {$[21]$} \\
\hline & $\begin{array}{l}\text { Chebulinic acid } \\
\text { Chebulagic Acid }\end{array}$ & $\begin{array}{l}1.36 \pm 0.36 \mu \mathrm{M}(\mathrm{H} 1 \mathrm{~N} 1 \mathrm{PR} 8) \\
\text { (Oseltamivir resistant and } \mathrm{H} 1 \mathrm{~N} 1 \\
\text { pdm09 viruses) } \\
\mathrm{CC}_{50}>100 \mu \mathrm{M}\end{array}$ & & Pre-clinical & {$[75]$} \\
\hline & Oseltamivir derivatives & $0.66 \mu \mathrm{M}(\mathrm{H} 5 \mathrm{~N} 1)$ & $\begin{array}{c}\text { Docking } \\
150 / 430 \\
\text { cavity }\end{array}$ & Pre-clinical & $\begin{array}{c}{[1,58,} \\
166]\end{array}$ \\
\hline & $\begin{array}{l}\text { Triazol oseltamivir derivatives } \\
\text { C1-modified oseltamivir } \\
\text { derivatives }\end{array}$ & $\begin{array}{l}0.05-0.15 \mu \mathrm{M}(\mathrm{H} 5 \mathrm{~N} 1, \mathrm{H} 5 \mathrm{~N} 2 \\
\text { and } \mathrm{H} 5 \mathrm{~N} 6) \\
0.1 \mu \mathrm{M}(\mathrm{H} 5 \mathrm{~N} 1, \mathrm{H} 5 \mathrm{~N} 6) \\
0.7 \mu \mathrm{M} \text { (Oseltamivir resistant } \\
\text { virus) }\end{array}$ & $\begin{array}{l}\text { Docking } \\
430 \text { cavity }\end{array}$ & Pre-clinical & {$[60]$} \\
\hline
\end{tabular}

a: Patch clamp assays [136] 
Table 2: Recent antiviral candidates targeting HA, their activity and structures of their complexes with HA

\begin{tabular}{|c|c|c|c|c|c|}
\hline Target & Compound / binding site & $\mathrm{IC}_{50} / \mathrm{CC}_{50}$ & PDB ID & Stage & references \\
\hline \multirow{8}{*}{ HA } & Arbidol / Stem region & $\begin{array}{l}4-12 \mu \mathrm{M} \\
\mathrm{CC}_{50}=59 \mu \mathrm{M}\end{array}$ & $5 \mathrm{~T} 6 \mathrm{~S}, 5 \mathrm{~T} 6 \mathrm{~N}$ & $\begin{array}{l}\text { Pre-clinical and } \\
\text { clinical } \\
\text { NCT03787459 }\end{array}$ & $\begin{array}{c}{[63,147,} \\
151]\end{array}$ \\
\hline & F0045(S) / Stem region & $\begin{array}{l}0.5-2 \mu \mathrm{M} \\
(\mathrm{H} 1 \mathrm{HA})\end{array}$ & $6 \mathrm{WCR}$ & Pre-clinical & {$[155]$} \\
\hline & JNJ4795 / Stem region & $\begin{array}{l}0.01-0.07 \mu \mathrm{M} \\
(\mathrm{H} 1 \mathrm{HA})\end{array}$ & $6 \mathrm{CF} 7$ & Pre-clinical & {$[141]$} \\
\hline & IY7640 / Stem region & $\begin{array}{l}0.5-7 \mu \mathrm{M} \\
(\mathrm{H} 1 \mathrm{HA}) \\
\mathrm{CC}_{50}>800 \mu \mathrm{M}\end{array}$ & $\begin{array}{l}\text { Docking } \\
\text { studies }\end{array}$ & Pre-clinical & [66] \\
\hline & CBS1117 / Stem region & $\begin{array}{l}3 \mu \mathrm{M} \\
\text { For H5 HA }\end{array}$ & $6 \mathrm{VMZ}$ & Pre-clinical & {$[2,45,55]$} \\
\hline & MB2746 / Stem region & $\begin{array}{l}0.3 \mu \mathrm{M} \\
(\mathrm{H} 1 \mathrm{HA}) \\
\mathrm{CC}_{50}>100 \mu \mathrm{M}\end{array}$ & $\begin{array}{l}\text { Docking } \\
\text { studies }\end{array}$ & Pre-clinical & {$[5]$} \\
\hline & $\begin{array}{l}\text { De novo design of "Mini- } \\
\text { binder" proteins }\end{array}$ & $\begin{array}{l}0.15-0.19 \mathrm{nM} \\
\text { (H3 and } \mathrm{H} 1 \mathrm{HA})\end{array}$ & $6 \mathrm{KUY}$ & & [129] \\
\hline & Peninddone & & HA1 and HA2 & Pre-clinical & {$[152]$} \\
\hline
\end{tabular}


Table 3: Inhibitors of PA, PA-PB1 interactions and PB1

\begin{tabular}{|c|c|c|c|c|c|}
\hline Target & Compound & $\mathrm{IC}_{50} / \mathrm{CC}_{50}$ & PDB ID & Stage & References \\
\hline \multirow{7}{*}{ PA } & Baloxavir marboxil & $\begin{array}{l}0.3-1 \mu \mathrm{M} \\
(\mathrm{H} 1 \mathrm{~N} 1 / \mathrm{H} 3 \mathrm{~N} 2)\end{array}$ & $\begin{array}{l}\text { 6FS6 } \\
6 \mathrm{FS} 9\end{array}$ & $\begin{array}{c}\text { Approved (2019) } \\
\text { NCT02954354 } \\
\text { NCT0294901 }\end{array}$ & [96] \\
\hline & L-742,001 & $\begin{array}{l}3 \mu \mathrm{M}(\mathrm{WT} H 1 \mathrm{~N} 1) \\
24 \mu \mathrm{M} \quad(\mathrm{WT} \quad \mathrm{H} 1 \mathrm{~N} 1 \\
\text { pdm09) } \\
236 \mu \mathrm{M}(\mathrm{H} 1 \mathrm{~N} 1 \mathrm{pdm} 09 \\
\text { PA F105S) }\end{array}$ & $\begin{array}{l}5 \mathrm{CGV} \\
5 \mathrm{D} 9 \mathrm{~J}\end{array}$ & $\begin{array}{c}\text { Clinical trial } \\
\text { NCT01526785 }\end{array}$ & {$[127]$} \\
\hline & RO7 & $\begin{array}{l}16 \text { nM (WT H1N1) } \\
3 \text { nM (H1N1 pdm09) }\end{array}$ & $5 \mathrm{VPX}$ & Pre-Clinical & {$[59,70]$} \\
\hline & Ana-0 & $0.8 \mu \mathrm{M}$ & Docking & Pre-clinical & {$[161]$} \\
\hline & Compound 22 & $110 \mathrm{pM}$ & 6E6W & Pre-clinical & {$[25]$} \\
\hline & $\mathrm{N}$-acylhydrazone derivatives & $11 \mu \mathrm{M}$ & 5EGA & Pre-clinical & {$[11]$} \\
\hline & $" 312 "$ & $\begin{array}{l}37 \mu \mathrm{M} \\
(\mathrm{H} 1 \mathrm{~N} 1, \quad \mathrm{H} 2 \mathrm{~N} 2 \quad \text { and } \\
\mathrm{H} 3 \mathrm{~N} 2)\end{array}$ & $\begin{array}{l}\mathrm{PA}-\mathrm{C}- \\
\text { terminal }\end{array}$ & Pre-Clinical & {$[78]$} \\
\hline \multirow{4}{*}{ PA-PB1 } & Compound 12a & $\begin{array}{l}0.9-2.7 \mu \mathrm{M} \\
\text { (FluA amantadine- \& } \\
\text { oseltamivir resistant, } \\
\text { FluB) }\end{array}$ & Docking & Pre-clinical & {$[164]$} \\
\hline & $\begin{array}{l}\text { Amino-acids adducts of diphenyl- } \\
\text { pyridine derivatives }\end{array}$ & $\begin{array}{l}39 \pm 2 \mu \mathrm{M} \\
(\mathrm{H} 1 \mathrm{~N} 1)\end{array}$ & Docking & Pre-clinical & {$[27]$} \\
\hline & $\begin{array}{l}\text { Cycloheptathiophene-3- } \\
\text { carboxamide }\end{array}$ & $\begin{array}{l}0.2 \mu \mathrm{M}-0.7 \mu \mathrm{M} \quad \mathrm{H} 1 \mathrm{~N} 1 \\
\text { pdm09, } \mathrm{H} 1 \mathrm{~N} 1 \\
\text { oseltamivir-resistant, } \\
\text { H3N2, Influenza B }\end{array}$ & Docking & Pre-clinical & {$[31],[94]$} \\
\hline & R151785 & $\begin{array}{lr}2.5,5.0 \mu \mathrm{M} & \\
\text { p09, } & \mathrm{H} 1 \mathrm{~N} 1 \\
\text { oseltamivir- } & \& \\
\text { amantadine } & \text { resistant } \\
\text { Influenza B } & \end{array}$ & Docking & Pre-clinical & {$[165]$} \\
\hline \multirow[b]{2}{*}{ PB1 } & Favipiravir & Broad-spectrum & & Approved (2014) & {$[160]$} \\
\hline & $\begin{array}{l}\beta \text {-d-N4-Hydroxycytidine/ EIDD- } \\
2801\end{array}$ & $\begin{array}{l}\text { Broad-spectrum } \\
\text { Influenza, SARS- } \\
\text { CoV2 }\end{array}$ & & $\begin{array}{c}\text { Clinical trial } \\
\text { NCT04405739 }\end{array}$ & $\begin{array}{l}{[140],} \\
{[122]}\end{array}$ \\
\hline
\end{tabular}


Table 4. Inhibitors of PB2 cap-binding, PB1-PB2, NP and NS1

\begin{tabular}{|c|c|c|c|c|c|}
\hline Target & Compound / binding site & $\mathrm{IC}_{50 /} \mathrm{CC}_{50}$ & PDB ID & Stage & References \\
\hline \multirow[t]{4}{*}{ PB2 } & Pimodividir (VX787) & $2.6 \mathrm{nM}$ & $4 \mathrm{P} 1 \mathrm{U}$ & Approved (2017) & {$[9,20]$} \\
\hline & $\begin{array}{l}5,7 \text {-difluoroindole derivative } \\
\text { of pimodivir }\end{array}$ & $11 \mathrm{nM}$ & $6 \mathrm{~S} 5 \mathrm{~V}$ & Pre-clinical & [84] \\
\hline & D 715-2441 & $\begin{array}{c}3.6-4.4 \mu \mathrm{M} \\
\text { (H1N1, H3N2, H5N1, } \\
\text { H7N9) }\end{array}$ & Docking & Pre-clinical & [77] \\
\hline & Cap analogs & $\begin{array}{l}7.5 \mu \mathrm{M} \\
\mathrm{H} 3 \mathrm{~N} 2\end{array}$ & $4 \mathrm{CB} 5$ & Pre-clinical & {$[100]$} \\
\hline $\begin{array}{l}\text { PB1- } \\
\text { PB2 }\end{array}$ & PP7 & $\begin{array}{c}1.4-9.5 \mu \mathrm{M} \\
\text { (Strain-specific) }\end{array}$ & Docking & Pre-clinical & {$[162]$} \\
\hline \multirow[t]{5}{*}{ NP } & Nucleozin & $\begin{array}{c}0.07 \mu \mathrm{M}(\mathrm{H} 1 \mathrm{~N} 1) \\
0.16 \mu \mathrm{M}(\mathrm{H} 3 \mathrm{~N} 2) \\
0.33 \mu \mathrm{M}(\mathrm{H} 5 \mathrm{~N} 1 \mathrm{Y} 287 \mathrm{H})\end{array}$ & $5 \mathrm{~B} 7 \mathrm{~B}$ & Pre-clinical & {$[64,98]$} \\
\hline & Compound 3 & $\begin{array}{c}0.1 \mu \mathrm{M} \\
(\mathrm{H} 1 \mathrm{~N} 1 \text { and } \mathrm{H} 5 \mathrm{~N} 1)\end{array}$ & 3RO5 & Pre-clinical & [46] \\
\hline & $\begin{array}{l}\text { 2-(4-chloro-3,5- } \\
\text { difluorophenylamino)thiazole- } \\
\text { 4-carboxamide derivatives }\end{array}$ & $0.11 \mu \mathrm{M}$ & Docking & Pre-clinical & [123], [150] \\
\hline & $\begin{array}{lll}\text { Naproxen } & & \\
& & \\
& & \\
\text { Naproxen } \quad \text { C0 } \quad \text { (Naproxen } \\
\text { derivative 2) }\end{array}$ & $\begin{array}{c}\text { Broad-spectrum FluA \& } \\
\text { Sars-CoV2 } \\
16 \pm 5 \mu \mathrm{M}(\mathrm{H} 1 \mathrm{~N}) \\
2.9 \pm 0.3 \mu \mathrm{M}(\mathrm{H} 1 \mathrm{~N} 1) \\
1.8 \mu \mathrm{M}(\mathrm{H} 1 \mathrm{~N} 1 \mathrm{pdm} 09) \\
1.3 \pm 0.2 \mu \mathrm{M} \text { (H1N1) } \\
0.7 \mu \mathrm{M} \text { (H1N1 pdm09, } \\
\mathrm{H} 3 \mathrm{~N} 2, \text { resistant to } \\
\text { oseltamivir) }\end{array}$ & Docking & Pre-clinical & $\begin{array}{c}{[33,73,} \\
134]\end{array}$ \\
\hline & $\begin{array}{l}\text { Hydroquinolinone derivatives } \\
\text { (NUD) }\end{array}$ & $\begin{array}{c}1.8-7.0 \mu \mathrm{M} \\
(\mathrm{H} 1 \mathrm{~N} 1)\end{array}$ & Docking & Pre-clinical & [79] \\
\hline \multirow[t]{2}{*}{ NS1 } & A22 & $\cong 1 \mu \mathrm{M}(\mathrm{H} 1 \mathrm{~N} 1 \mathrm{PR} 8)$ & Docking & Pre-clinical & [68] \\
\hline & ML303 & $\begin{array}{c}0.7-17 \mu \mathrm{M} \\
(\mathrm{H} 1 \mathrm{~N} 1 \mathrm{pdm} 09, \mathrm{H} 3 \mathrm{~N} 2)\end{array}$ & HTS & Pre-clinical & [99] \\
\hline
\end{tabular}


Table 5. Drugs targeting host-cell component at different level of viral cycle stages.

\begin{tabular}{|c|c|c|c|c|}
\hline Viral cycle stage & Drug name & Mode of action & Research phase & References \\
\hline \multirow{10}{*}{ Viral entry } & DAS181 & $\begin{array}{l}\text { Sialidase - removes sialic } \\
\text { acid receptors }\end{array}$ & Phase I/II & $\begin{array}{l}\text { Moss et al. 2012[88] } \\
\text { Zenilman et al. } \\
\text { 2015[163] }\end{array}$ \\
\hline & Bafilomycin A1 & \multirow{4}{*}{$\begin{array}{c}\text { V-ATPase inhibitors - } \\
\text { inhibits endosomal } \\
\text { acidification }\end{array}$} & \multirow{4}{*}{ preclinical } & $\begin{array}{l}\text { Yeganeh } \text { et al. } \\
2015[158]\end{array}$ \\
\hline & Concanamycin & & & Müller et al. 2011[90] \\
\hline & Diphyllin & & & Chen et al. 2013[14] \\
\hline & Saliphenylhalamide & & & Bimbo et al. 2013[7] \\
\hline & Aprotinin & \multirow{2}{*}{$\begin{array}{l}\text { Protease inhibitors - inhibit } \\
\text { HA0 cleavage }\end{array}$} & Approved (2011) & $\begin{array}{l}\text { Zhirnov et al. } \\
\text { 2011[169] }\end{array}$ \\
\hline & Camostat & & \multirow{5}{*}{ Preclinical } & $\begin{array}{l}\text { Yamaya et al. } \\
\text { 2015[154] }\end{array}$ \\
\hline & Dynasore & \multirow{3}{*}{ Inhibition of internalization } & & de Vries et al. \\
\hline & EIPA & & & $2011[30]$ \\
\hline & Fattiviracin & & & Harada et al. 2007[51] \\
\hline $\begin{array}{c}\text { Nuclear import of } \\
\text { vRNP }\end{array}$ & Ivermectin & Inhibits importin- $\alpha / \beta$ & & Gotz et al. 2016[47] \\
\hline \multirow{7}{*}{$\begin{array}{c}\text { Genomic } \\
\text { replication \& } \\
\text { protein synthesis }\end{array}$} & TG003 & \multirow{2}{*}{$\begin{array}{l}\text { CLK1 inhibitors -Regulation } \\
\text { of splicing - decrease in M2 } \\
\text { mRNA expression }\end{array}$} & & Karlas et al. 2010[65] \\
\hline & Clypearin & & & Zu et al. 2015[171] \\
\hline & $\begin{array}{l}\text { Corilagin } \\
\text { Sylvestrol }\end{array}$ & \multirow{2}{*}{$\begin{array}{l}\text { eIF4A inhibitors - inhibit } \\
\text { viral protein synthesis }\end{array}$} & & \multirow{2}{*}{ Slaine et al. 2017[126] } \\
\hline & Pateamine & & & \\
\hline & Ribavirin & \multirow[b]{2}{*}{ Nucleoside analogue } & Approved (1986) & Durr et al. 1975[38] \\
\hline & $\begin{array}{l}\text { Viramidine (ribavirin } \\
\text { prodrug) }\end{array}$ & & Phase III (HCV) & $\begin{array}{l}\text { Sidwell et al. } \\
2005[125]\end{array}$ \\
\hline & \multirow{2}{*}{ Cyclosporin A } & $\begin{array}{c}\text { Inhibits host RNA } \\
\text { polymerase II } \\
\end{array}$ & \multirow{7}{*}{ preclinical } & \multirow{2}{*}{ Liu et al. 2012[77] } \\
\hline \multirow{8}{*}{$\begin{array}{l}\text { vRNP nuclear } \\
\text { export }\end{array}$} & & $\begin{array}{c}\text { Inhibits nuclear export of } \\
\text { vRNPs }\end{array}$ & & \\
\hline & Verdinexor & \multirow{2}{*}{ Exportin 1 inhibitors } & & $\begin{array}{c}\text { Perwitasari et al. [101] } \\
2014\end{array}$ \\
\hline & DP2392-E10 & & & $\begin{array}{c}\text { Chutiwitoonchai et al. } \\
2017[19]\end{array}$ \\
\hline & CI-1040 & MEK inhibitor - nuclear & & $\begin{array}{l}\text { Haasbach et al. } \\
\text { 2017[49] }\end{array}$ \\
\hline & UO126 & retention of VRNP complex & & $\begin{array}{l}\text { Pleschka et al. } \\
\text { 2001[108] }\end{array}$ \\
\hline & PBP10/BOC2 & $\begin{array}{c}\text { Formyl peptide receptor } 2 \\
\text { antagonists - Raf/MEK/ERK } \\
\text { inhibition } \\
\end{array}$ & & Courtin et al. 2017[24] \\
\hline & Trametinib & $\begin{array}{l}\text { MEK1/2 inhibitor }- \text { inhibition } \\
\text { of vRNP export }\end{array}$ & $\begin{array}{c}\text { Approved } \\
\text { (cancer) }\end{array}$ & $\begin{array}{c}\text { Schräder } \text { et al. } \\
\text { 2018[119] }\end{array}$ \\
\hline & Dapivirine & $\begin{array}{c}\text { Reverse transcriptase } \\
\text { inhibitor - inhibition of vRNP } \\
\text { export }\end{array}$ & Phase III (HIV) & Hu et al. 2017[53] \\
\hline \multirow{4}{*}{$\begin{array}{l}\text { Apical transport } \\
\text { and budding }\end{array}$} & Nitazoxanide & $\begin{array}{l}\text { Anti-parasitic - Inhibition of } \\
\text { HA maturation \& transport }\end{array}$ & Phase III & $\begin{array}{l}\text { Rossignol et al. } \\
\text { 2009[113] }\end{array}$ \\
\hline & Ruxolitinib & $\begin{array}{l}\text { Virion formation \& vRNA } \\
\text { incorporation inhibition }\end{array}$ & $\begin{array}{c}\text { Approved } \\
\text { (myelofibrosis) }\end{array}$ & $\begin{array}{l}\text { Watanabe et al. } \\
2015[148]\end{array}$ \\
\hline & U18666A & $\begin{array}{l}\text { Hydrophobic polyamine - } \\
\text { Reduces plasma membrane } \\
\text { cholesterol level and } \\
\text { decreases virion egress }\end{array}$ & \multirow[t]{2}{*}{ preclinical } & Musiol et al. 2013 [92] \\
\hline & Clonidine & $\begin{array}{l}\text { alpha2-adrenergic receptors } \\
\text { inhibitor - Inhibits transport } \\
\text { of HA transport to plasma } \\
\text { membrane }\end{array}$ & & Matsui et al. 2018[82] \\
\hline
\end{tabular}


Table 6. Drugs targeting host-cell signaling pathway and host-responses that are crucial for influenza replication cycle.

\begin{tabular}{|c|c|c|c|c|}
\hline $\begin{array}{c}\text { Host signalling } \\
\text { pathway/response }\end{array}$ & Drug name & Mode of action & Research phase & References \\
\hline \multirow{4}{*}{ NF-kB pathway } & Acetylsalicylic acid & \multirow{4}{*}{$\begin{array}{c}\text { Immune dysregulation } \\
\text { Inhibition of caspase/vRNP } \\
\text { export inhibition }\end{array}$} & Approved & $\begin{array}{c}\text { Mazur et al. } \\
\text { 2007[83] }\end{array}$ \\
\hline & $\begin{array}{c}\text { pyrrolidine } \\
\text { dithiocarbamate }\end{array}$ & & preclinical & $\begin{array}{c}\text { Wiesener et al. } \\
\text { 2011[149] }\end{array}$ \\
\hline & SC75741 & & preclinical & $\begin{array}{l}\text { Ehrhardt et al. } \\
\text { 2013[39] } \\
\text { Haasbach et al. } \\
\text { 2013[49] }\end{array}$ \\
\hline & LASAG & & Phase II & $\begin{array}{l}\text { Droebner et al. } \\
2017[35] \\
\text { Scheuch et al. } \\
2018[116]\end{array}$ \\
\hline $\begin{array}{c}\text { C-Jun-N-terminal- } \\
\text { kinase }\end{array}$ & SP600125 & $\begin{array}{c}\text { C-Jun N-Terminal kinase } \\
\text { inhibitor - Immune } \\
\text { dysregulation }\end{array}$ & preclinical & $\begin{array}{l}\text { Nacken et al. } \\
\text { 2012[93] }\end{array}$ \\
\hline p38 MAPK & NJK14047 & Immune dysregulation & preclinical & Choi et al. 2016[18] \\
\hline $\mathrm{HMG}-\mathrm{CoA}$ & Statins & Immunomodulation & Phase II & $\begin{array}{l}\text { Fedson et al. } \\
\text { 2013[43] } \\
\text { Mehrbod } \text { et al. } \\
\text { 2014[85] } \\
\text { Fedson et al. } \\
\text { 2018[43] }\end{array}$ \\
\hline TNF-alpha & Etanercept & $\begin{array}{l}\text { Anti-inflammatory drug - } \\
\text { Prevents TNF-mediated lung } \\
\text { injury and edema }\end{array}$ & preclinical & Shi et al. 2013[124] \\
\hline \multirow[b]{2}{*}{ Nox2 } & Apocynin & $\begin{array}{c}\text { ROS scavenger, inhibits } \\
\text { Nox2 activity }\end{array}$ & preclinical & \multirow{2}{*}{$\begin{array}{c}\text { Ye et al. } 2015[157] \\
\text { Oostwoud et al. } \\
2016\end{array}$} \\
\hline & Ebselen & $\begin{array}{l}\text { ROS scavenger and } \\
\text { glutathione peroxidase } \\
\text { mimetic, inhibits Nox } 2\end{array}$ & preclinical & \\
\hline \multirow[b]{2}{*}{$\begin{array}{l}\text { Lipoxygenase \& } \\
\text { COX pathways }\end{array}$} & Celecoxib & Immune dysregulation & Phase III & \multirow{2}{*}{$\begin{array}{c}\text { Davidson et al. } \\
\text { 2018[28] } \\
\text { Carey et al. } \\
\text { 2010[12] } \\
\text { Zheng et al. } \\
\text { 2008[167] }\end{array}$} \\
\hline & Mesalazine & Immune dysregulation & preclinical & \\
\hline \multirow{2}{*}{$\begin{array}{l}\text { Type III IFN } \\
\text { response }\end{array}$} & Type III IFN & \multirow{2}{*}{$\begin{array}{l}\text { Induction of type III IFN } \\
\text { response }\end{array}$} & preclinical & $\begin{array}{l}\text { Davidson et al. } \\
\text { 2016[29] } \\
\text { Kim et al. 2017[67] } \\
\end{array}$ \\
\hline & Diltiazem & & Phase II & $\begin{array}{l}\text { Pizzorno et al. } \\
\text { 2019[106, 107] }\end{array}$ \\
\hline
\end{tabular}


A
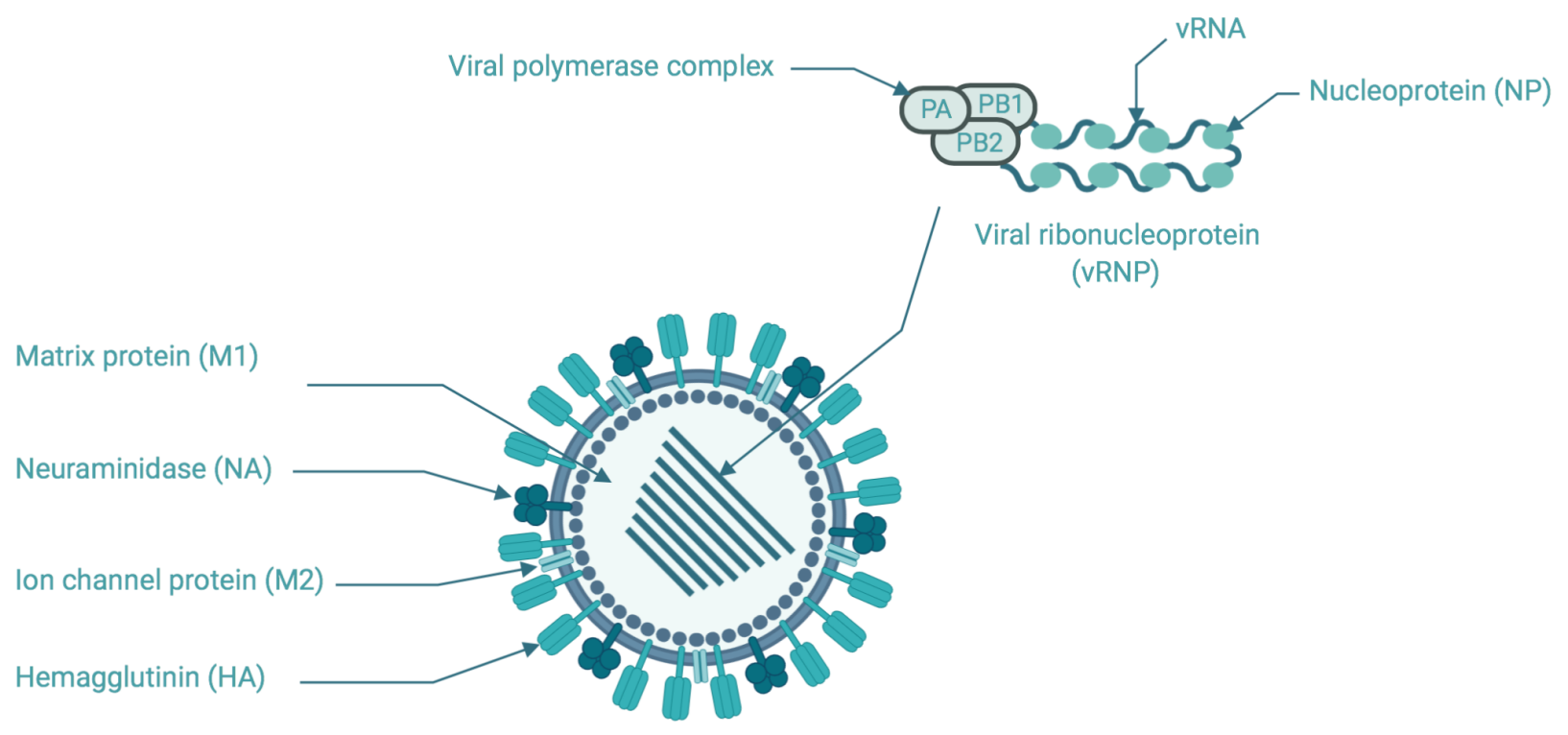

B

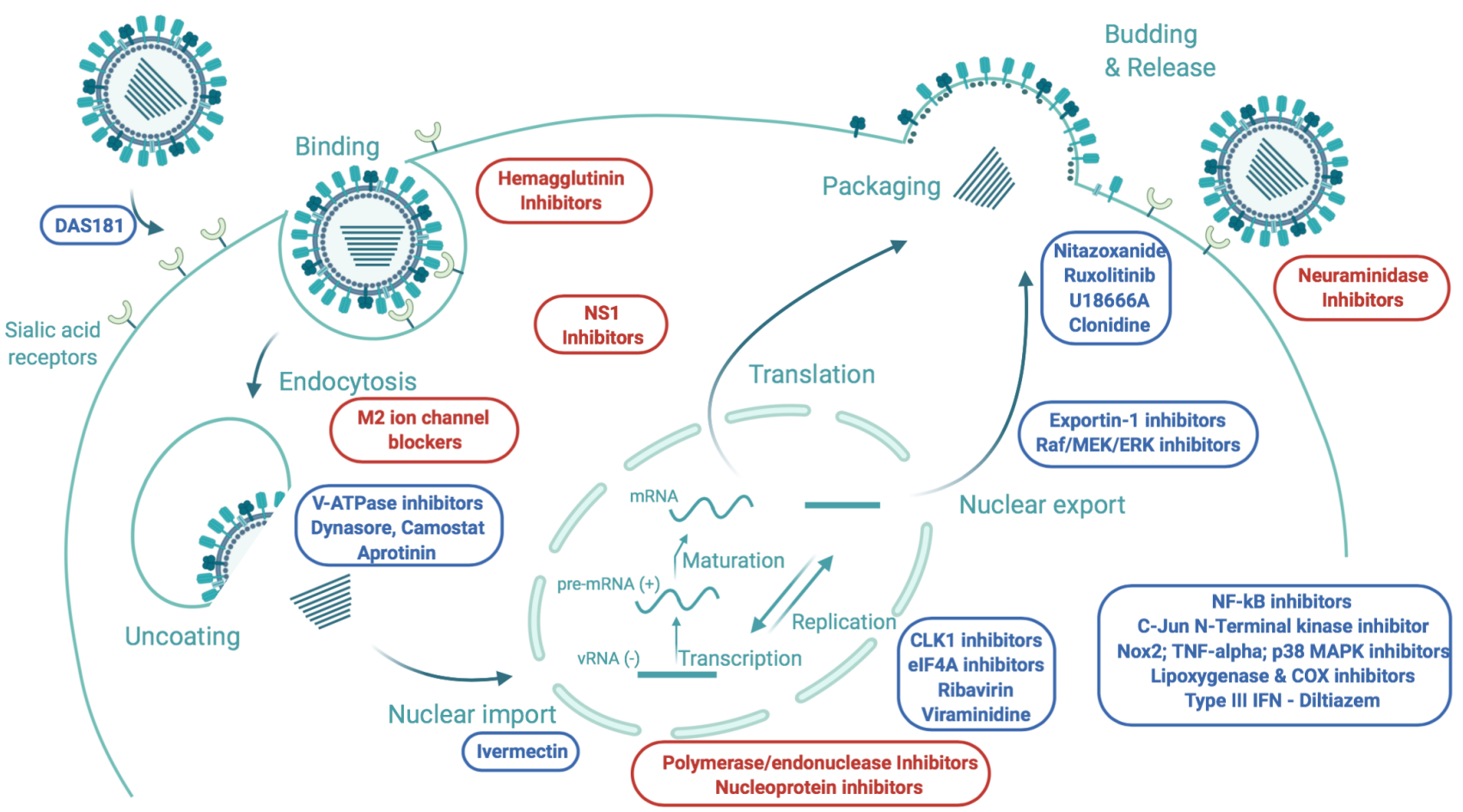




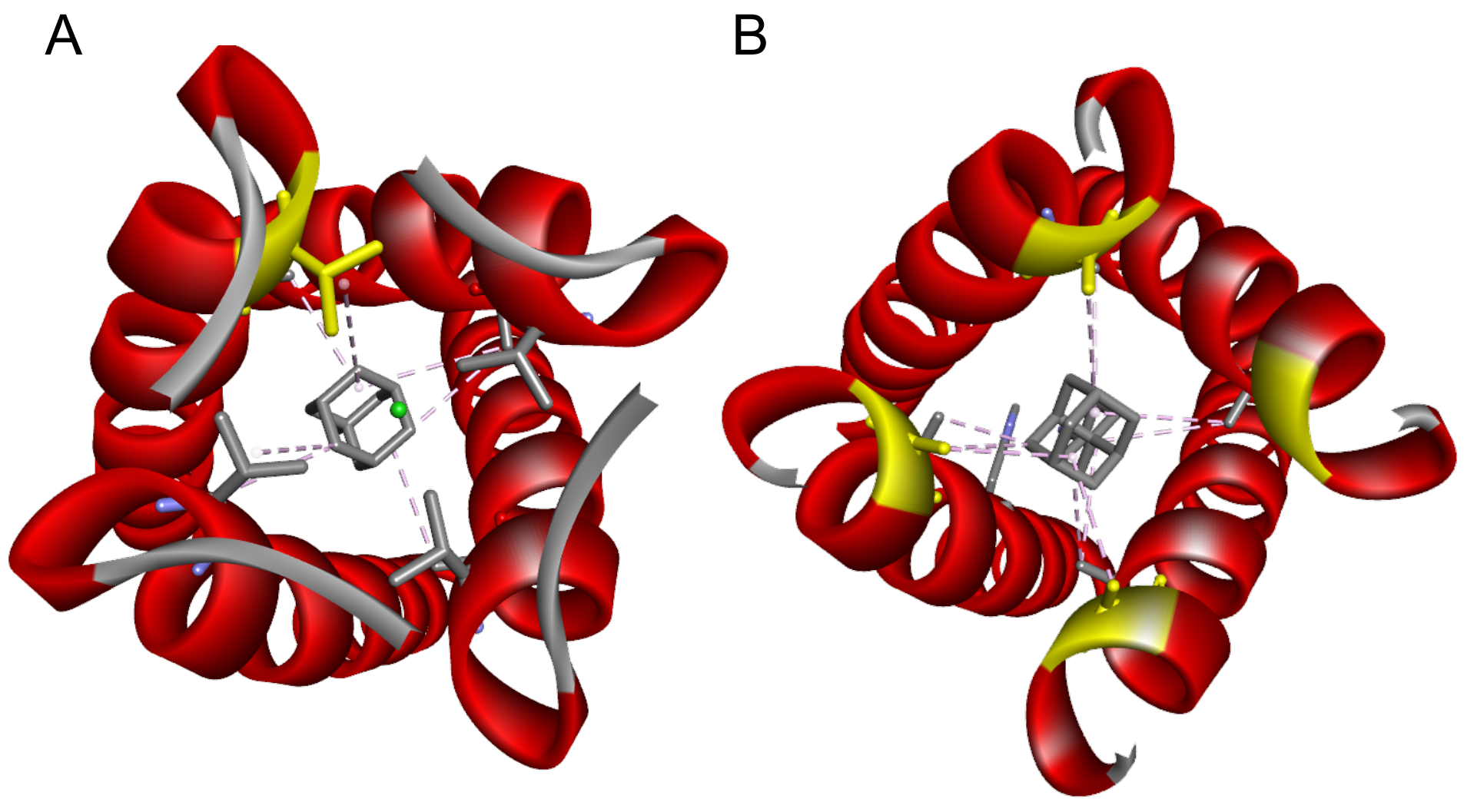

Figure 2 
<smiles>CCOC(=O)C1=CC(OC(CC)CC)C(NC(C)=O)C(N)C1</smiles><smiles>CC(=O)N[C@H]1[C@@H](N=C(N)N)C=C(C(=O)O)O[C@H]1[C@H](O)C(O)CO</smiles>

Zanamivir<smiles>CCOC(=O)c1c(CSc2ccccc2)n(C)c2cc(Br)c(O)c(CN(C)C)c12</smiles>

Ardibol<smiles>CCC(CC)C(NC(C)=O)[C@H]1C(N=C(N)N)CC(C(=O)O)C1O</smiles>

Peramivir<smiles>COC(C(O)CO)C1OC(C(=O)O)=CC(N=C(N)N)C1NC(C)=O</smiles>

Laninamivir 
A

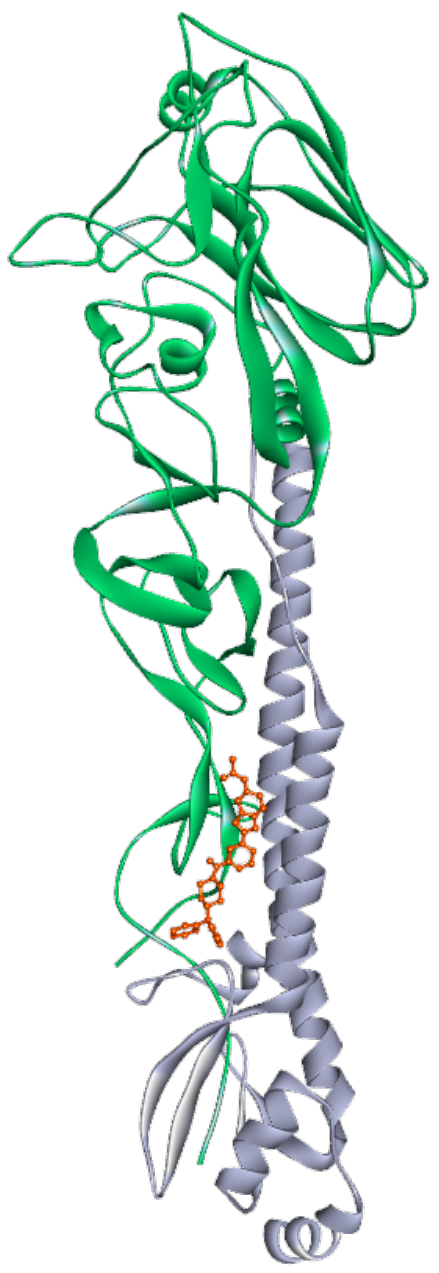

B

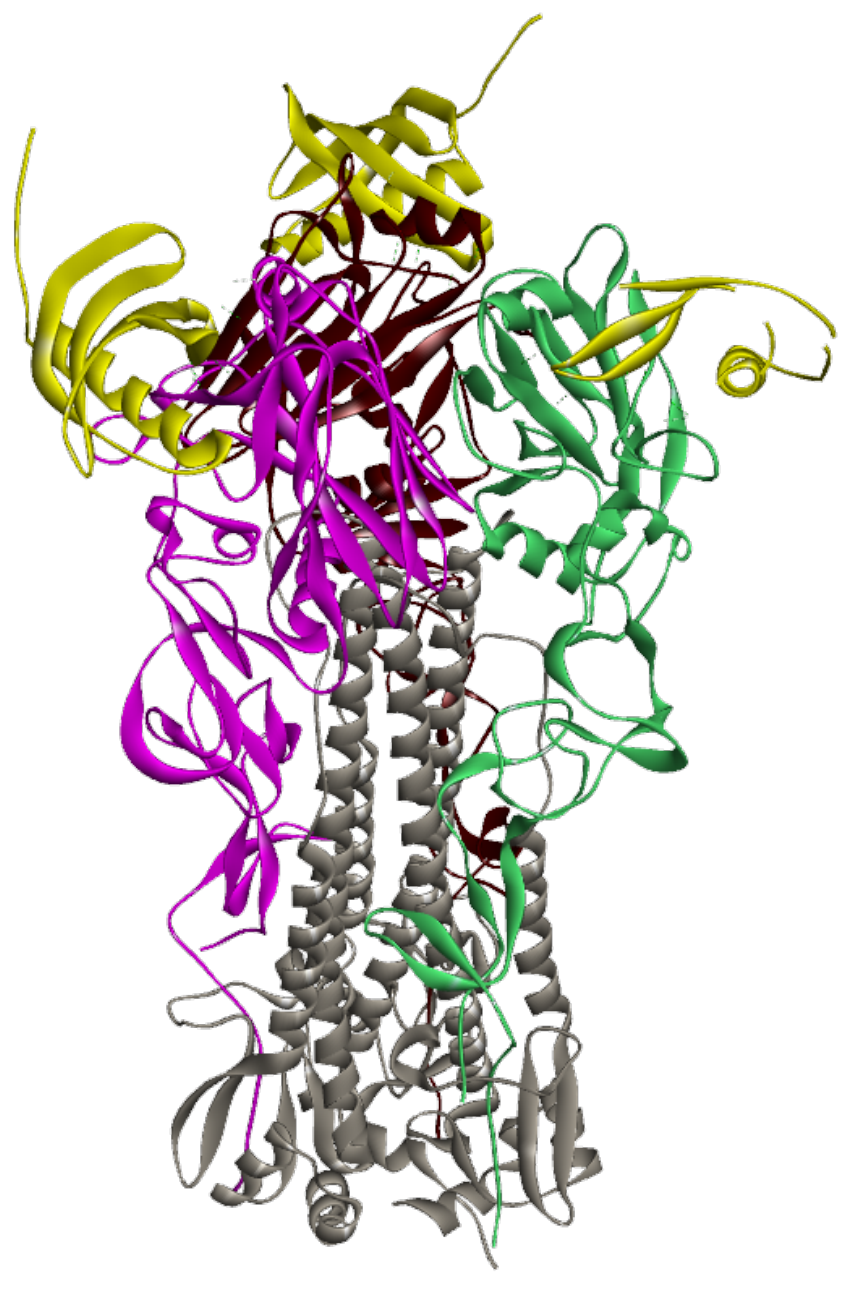

Figure 4 
A

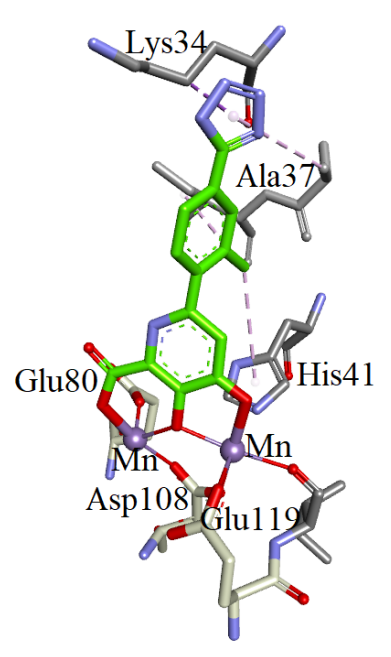

C

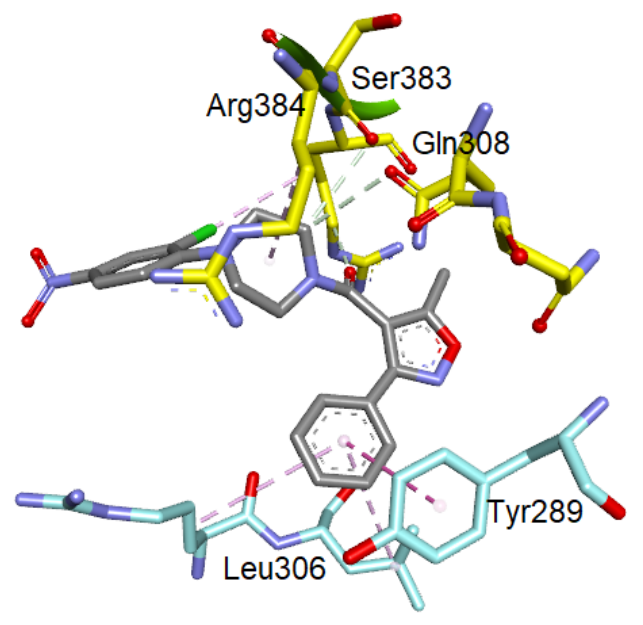

B

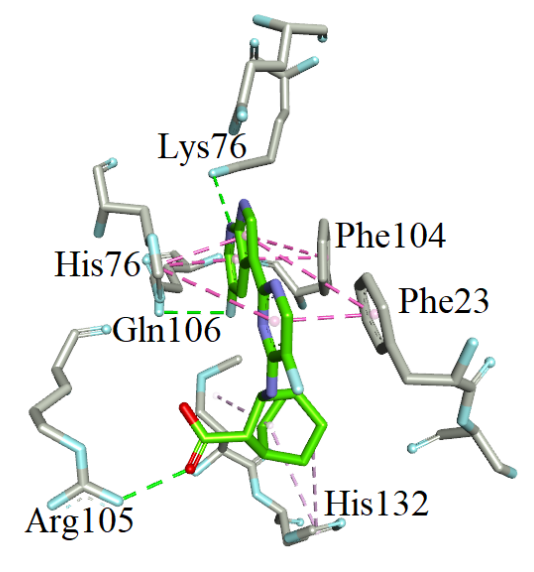

D

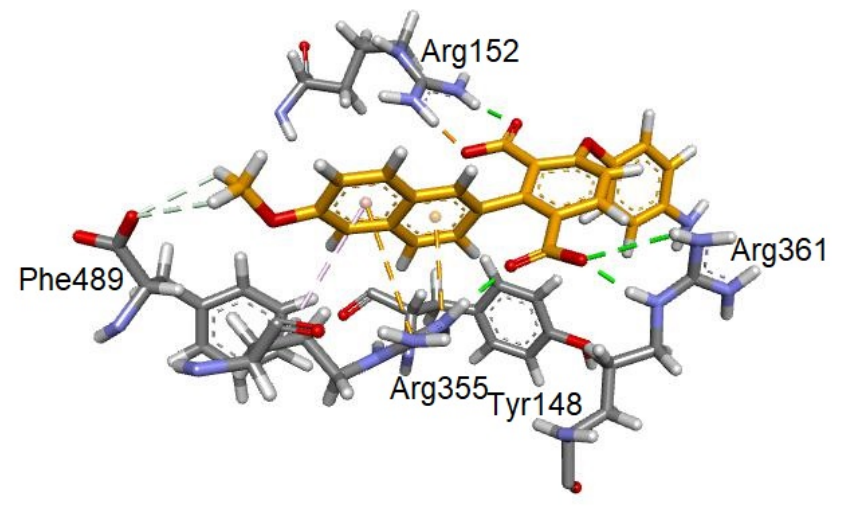

Figure 5 
<smiles>C[C@@]12COCCN(C(=O)c3c(O)c(=O)ccn3N1[C@H]1c3ccccc3SCc3c1ccc(F)c3F)C2=O</smiles><smiles>NC(=O)c1nc(F)c[nH]c1=O</smiles><smiles>CCCCC(C)(C)C</smiles>

Pimodivir

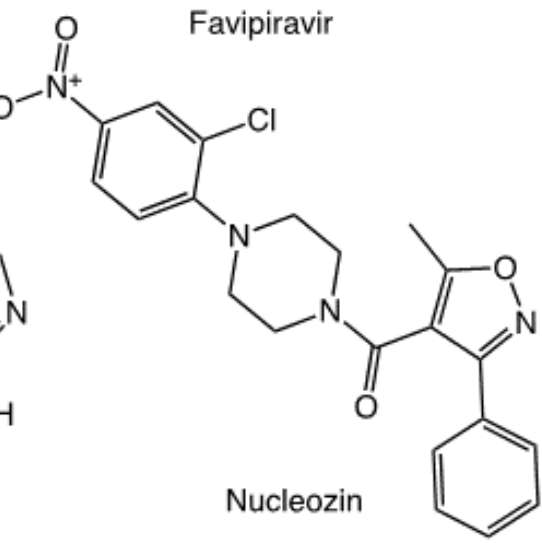<smiles>COc1ccc2cc([C@@H](C)C(=O)O)ccc2c1</smiles> 